\title{
Current Perspectives Regarding Stem Cell-Based Therapy for Liver Cirrhosis
}

\author{
Kyeong-Ah Kwak, ${ }^{1}$ Hyun-Jae Cho, ${ }^{2}$ Jin-Young Yang, ${ }^{3}$ and Young-Seok Park ${ }^{1}{ }^{1}$ \\ ${ }^{1}$ Department of Oral Anatomy, School of Dentistry, Seoul National University and Dental Research Institute, Seoul, Republic of Korea \\ ${ }^{2}$ Department of Preventive and Social Dentistry, School of Dentistry, Seoul National University and Dental Research Institute, \\ Seoul, Republic of Korea \\ ${ }^{3}$ Department of Dental Hygiene, Daejeon Institute of Science and Technology, Daejeon, Republic of Korea
}

Correspondence should be addressed to Young-Seok Park; ayoayo7@snu.ac.kr

Received 22 November 2017; Accepted 16 January 2018; Published 29 January 2018

Academic Editor: Emmanuel Tsochatzis

Copyright (C) 2018 Kyeong-Ah Kwak et al. This is an open access article distributed under the Creative Commons Attribution License, which permits unrestricted use, distribution, and reproduction in any medium, provided the original work is properly cited.

Liver cirrhosis is a major cause of mortality and a common end of various progressive liver diseases. Since the effective treatment is currently limited to liver transplantation, stem cell-based therapy as an alternative has attracted interest due to promising results from preclinical and clinical studies. However, there is still much to be understood regarding the precise mechanisms of action. A number of stem cells from different origins have been employed for hepatic regeneration with different degrees of success. The present review presents a synopsis of stem cell research for the treatment of patients with liver cirrhosis according to the stem cell type. Clinical trials to date are summarized briefly. Finally, issues to be resolved and future perspectives are discussed with regard to clinical applications.

\section{Introduction}

Liver fibrosis results from sustained injury, which can be inflicted by various factors such as viruses, drugs, alcohol, metabolic diseases, and autoimmune attacks [1]. Prolonged exposure to these harmful factors causes hepatocyte apoptosis, inflammatory cell recruitment, endothelial cell impairment, and, lastly, activation of hepatic stellate cells, the major cells involved in liver fibrosis. Liver fibrosis is a kind of scar tissue formation in response to liver damage [2-9]. Histologically, it is caused by an imbalance between extracellular matrix synthesis and degradation [10-12].

Liver cirrhosis is a condition where scar tissue replaces the healthy tissue of the liver and regenerative nodules with surrounding fibrous bands develop as a result of the injury [13]. Cirrhosis is the common end of progressive liver disease of various causes, resulting in chronic liver failure entailing complications such as hepatic encephalopathy, spontaneous bacterial peritonitis, ascites, and esophageal varices [14]. Unfortunately, the majority of cases are usually in an irreversible state when diagnosed. Despite current advancements in its management $[15,16]$, cirrhosis was the 14th leading cause of death worldwide in 2012 [17]. Orthotopic liver transplantation is known to be the only definite solution to end-stage cirrhosis.

However, several problems preclude the prevalent application of the procedure, including immunological rejection and the scarcity of donor sources [18].

In fact, the liver has an inherent regenerative capacity to a substantial degree [19], and, thus, the cessation of those harmful factors may prevent further progression of fibrosis and reverse the situation in some cases [20]. In cases where hepatocyte proliferation is insufficient for recovery from liver injury, bipotent resident liver progenitor cells (LPC) are activated and participate in liver regeneration by differentiating into hepatocytes and biliary epithelial cells $[19$, 21-23]. However, fibrosis is inevitable when regeneration is exceeded by destruction. Clinical signs of liver failure usually appear after about 80 to $90 \%$ of the parenchyma has been destroyed.

Hepatocyte transplantation has been proposed as an alternative approach to transplantation, since hepatocytes 
have been proven to be strongly associated with liver repair [24-28]. While hepatocyte transplantation is safe in humans, its applicability remains limited due to organ availability, failure of donor engraftment, weak viability in cell culture, and vulnerability to cryopreservation damage [25, 26, 29-32].

Instead of hepatocytes, the transplantation of stem cells has shown therapeutic potential for liver function improvement according to recent experimental studies and human studies [20, 26, 33-40]. Although they remain unclear, the major potential mechanisms have been proposed as a twofold; one is the improvement of the microenvironments through paracrine effects, and the other is the replacement of functional hepatocytes [20].

To date, several kinds of stem cells have been investigated for their therapeutic feasibility and clinical potential in liver cirrhosis [41-43]. The present article briefly reviews the current literature according to the types of stem cells and discusses the future perspectives of stem cell-based therapy in liver cirrhosis.

\section{Sources of Stem Cells}

Hepatocytes obtained via autopsy of patients who received bone marrow transplantation suggested that they are pluripotent cells in bone marrow $[44,45]$. Currently, at least three types of bone marrow-derived cells are known to differentiate into hepatocyte-like cells (HLCs): hematopoietic stem cells (HSCs), mesenchymal stem cells (MSCs), and endothelial progenitor cells (EPCs), though early infusion trials did not discriminate the origins of those cells from bone marrowderived stromal cells with some improvement [32, 46-52]. A large number of preclinical studies have proven the feasibility of HSCs, MSCs, and EPCs to restore hepatic function in models of liver injury [53-57]. In addition, other stem cells including embryonic stem cells (ESCs) and induced pluripotent stem cells (iPSCs) can also be differentiated into HLCs [58-60]. HLCs can contribute to the remodeling of cirrhotic liver [20,61-68].

2.1. Hematopoietic Stem Cells. HSCs are the predominant population of stem cells within bone marrow and express CD34 as the cell surface marker. They can renew themselves and differentiate into progenitor cells $[69,70]$. HSCs can easily be made to leave the bone marrow and circulate into the blood. The mobilization of HSCs resident in bone marrow can be brought about at a low magnitude through tissue injury [71, 72] or in high amounts after artificial priming $[73,74]$. Granulocyte-colony stimulating factor is the most widely studied and widely used mobilizing agent [75-80].

HLCs derived from HSCs have been demonstrated to contribute to liver regeneration $[65,81-83]$. In general, two mechanisms were proposed with substantial support. One was the de novo generation of hepatocytes through transdifferentiation, and the other was the genetic reprogramming of resident hepatocytes through cell fusion [45, 46, 84]. However, the infused HSCs do not seem to be a primary source of newly generated hepatocytes $[85,86]$. Rather, their roles are likely to be associated with macrophages, which produce collagenases, phagocytose dead cells, and facilitate liver regeneration [87-89]. Therefore, the clinical benefit of HSC therapy occurs through paracrine signaling interactions involving various cytokines and growth factors [86, 90, 91]. Furthermore, HSCs likely stimulate neoangiogenesis [92].

2.2. Endothelial Progenitor Cells. EPCs are immature endothelial cells that can be found in both peripheral blood vessels and bone marrow. They arise from hemangioblasts and participate in the neovascularization of damaged tissue throughout the whole body [93-99]. Due to their common expression of CD34, EPCs and HSCs are assumed to have a common precursor [94, 100-106]. However, EPCs are likely to be differentiated from various cell lineages, as evidenced by their diverse surface markers [102, 104, 107-113].

The transplantation of EPCs led to the suspension of liver fibrosis by suppressing activating HSCs, according to an animal study [55]. They also promoted hepatocyte proliferation and increased matrix metalloproteinase activity [114]. These effects were associated with increased secretion of growth factors [115-117].

2.3. Mesenchymal Stem Cells. MSCs are a rarer population in bone marrow compared to HSCs, which are capable of selfrenewal and differentiation into HLCs as well as cell types of mesenchymal origin [68, 118-128]. Traditionally, MSCs have frequently been isolated from bone marrow [129], but, recently, they have been obtained from many other tissues including umbilical cord blood, adipose tissue, and placenta [130-142]. There seems to be source-dependent differences among MSCs [143].

As a therapeutic advantage, MSCs can easily be expanded ex vivo without losing their differentiation potential, and they can also be migrated to the injured areas in response to homing signals [1]. Furthermore, the MSCs have immunomodulatory properties [144-156], through both adaptive and innate immune systems $[157,158]$, and secrete a variety of trophic factors such as growth factors and cytokines beneficial for liver regeneration [159-164]. Some of these trophic factors are known to revive hepatocytes reaching their replicative senescence $[38,165,166]$. With these advantages as a cell therapy source, the MSCs are the most widely studied stem cells, both experimentally and clinically [59, 167-174].

The precise therapeutic mechanisms of MSCs in liver regeneration have yet to be sufficiently elucidated. Accumulating evidence strongly supports the inference that the effects of MSCs are mediated mostly via paracrine mechanisms rather than transdifferentiation [175-179], although the infused bone marrow-derived MSCs (BM-MSCs) have been shown to engraft into host livers and ameliorate fibrosis in experimental animal models of liver fibrosis [54, 180-183]. MSC transplantation has also demonstrated preclinical efficacy in mitigating liver fibrosis as in other organs $[53,54,181,184-187]$. Strategies to enhance the effects of MSC in cirrhosis have been investigated, including the facilitation of transdifferentiation into functional hepatocytes $[59,68,120,168,188]$. Interestingly, however, the in vivo transdifferentiation of MSCs into hepatocytes has been rarely observed in animal models [54, 189-192]. 
Rather, the MSCs downregulate proinflammatory and fibrogenic cytokine activity, stimulate hepatocellular proliferation, and promote collagen degradation by matrix metalloproteinase [53, 54, 181, 190-193]. The paracrine effects modulate the functioning of activated hepatic stellated cells [56, 194, 195]. Evidence from treatment with MSC-conditioned medium reconfirmed the paracrine effects of MSCs such as the increased proliferation and reduced apoptosis of hepatocytes subsequent to the upregulation of several antiinflammatory and antifibrotic cytokines $[196,197]$. How each of these signaling molecules individually contributes to hepatic regeneration, however, remains to be further elucidated [46].

2.4. Embryogenic Stem Cells. Thomson et al. derived and characterized human ESCs from the inner mass of a blastocyst for the first time in 1998 [198]. ESCs have pluripotency and can differentiate into hepatocyte-like cells, which possess some properties of mature hepatocytes [199-205]. Hepatocytes generated from ESCs in vitro and hepatocytes differentiated from ESCs have been demonstrated to express a number of hepatocyte-related genes and mimic hepatic functions. ESC-derived hepatocytes bear the typical morphology of mature hepatocyte and colonized liver tissue upon transplantation. The cardinal pathways associated with activin $\mathrm{A}$ and Wnt3a and FGF signaling are essential for ESC to differentiate into hepatic lineage [200, 206-217]. ESC-derived hepatocyte-like cells promoted the cell recovery of injured liver by cell replacement [201, 210, 218, 219] and paracrine mechanism to stimulate endogenous regeneration. However, it still remains unclear whether ESCsderived hepatocytes have the origin of definitive endoderm or primitive endoderm. The recent study using ESCs combined with MSCs showed promising results [201, 220]. Human ESCs are likely resistant to cryopreservation, which mature hepatocytes can hardly endure. Studies using ESCs have provided the molecular basis of hepatocyte differentiation. Despite the promising results, the application of human ESCs has always been precluded by practical and ethical barriers.

2.5. Induced Pluripotent Stem Cells. The iPSCs were first developed by Dr. Yamanaka from mouse fibroblasts in 2006, which were reprogrammed into a state of pluripotency like that of ESCs [98]. These iPSCs have been reported to be differentiated to neuron cells [221], neurospheres [222], cardiomyocytes [223-225], hematopoietic and endothelial cells [226], and insulin-secreting islet-like clusters [227]. A number of protocols to differentiate iPSCs into HLCs have been described [60, 228-242]. Unfortunately, the iPSCderived HLCs showed minimal activity, reaching around 0.3 to $10 \%$ of the activity of primary hepatocytes [231].

In animal experiments, the iPSC-derived HLC transplantation halted lethal fulminant hepatic failure, promoted regeneration, and improved function [234, 235, 243-245]. Due to immunosuppression and possible unlimited supply, the patient-corrected human iPSCs have great potential to be utilized in personalized cell therapy [230, 246, 247]. However, several issues regarding iPSC usage should be properly addressed prior to clinical application, including teratoma formation and tumorigenicity, controversy about immunogenicity, long-term safety and efficacy, and optimal reprogramming and manufacturing processes [248-250].

2.6. Other Cells. Fetal hepatic progenitor cells have been of interest due to their ease of isolation, high proliferation rate, superior repopulation capacity, lower immunogenicity, and resistance to cryopreservation in contrast to adult counterparts [251-256]. Annex stem cells derived from umbilical cord, placenta, and amniotic fluid have easily accessible sources, but they can be categorized as MSCs with respective differences according to their origin [257-261].

\section{Clinical Trials Using Stem Cell-Based Therapy}

Early autologous bone marrow-derived stem cell transplantation resulted in amelioration of liver injury and functional improvements, and they probably included a mixed cell population of HSCs, MSCs, and EPCs [53, 55, 82, 124, $262,263]$. A number of single-arm, phase I clinical studies with small samples have been performed and have shown some promise in patients with liver cirrhosis [31, 48, 49, 123, 264-270]. The infusion of bone marrow-derived stem cells has sometimes been used as a supportive measure for patients with partial hepatectomy [271-273]. Although the precise mechanisms are still unresolved, the findings from those studies with small sample sizes have provided assurance that no critical complications occurred after the procedures. Furthermore, the posttransplantation incidence of hepatocellular carcinoma was not increased despite the enduring concern $[68,274,275]$.

A trial using human fetal liver-derived stem cells enrolling 25 patients with cirrhosis demonstrated improved mean model for end-stage liver disease (MELD) scores [276], although long-term outcomes were not properly reported [277]. There have been several clinical studies using HSCs with promising results [278-281] since Pai et al. [37] reported that the autologous infusion of CD34+ cells improved the serum albumin level and the Child-Pugh score. However, most results have shown only temporary effects and there still remains many questions yet to be answered [280].

The most frequently studied stem cells are the MSCs; thus, their mechanisms of actions are also better understood. In particular, BM-MSCs have been prevalently utilized. In two early pilot studies, autologous injections of BM-MSCs in a few patients were reported to result in improvement of liver function $[35,267]$. The safety and short-term efficacy of BM-MSCs were evidenced in two groups of 20 patients each, which showed significantly improved Child-Pugh and MELD scores [47]. Subsequent studies continued to confirm the efficacy of BM-MSC transplantation in varying sizes of samples [282-285]. Notably, one randomized controlled trial using autologous MSCs in cirrhotic patients failed to demonstrate beneficial effects, in contrast to the prior reports [286].

The transplanted cells were mostly infused intravenously, except in three studies using the hepatic artery [284, 285] 
and one featuring direct injection into the spleen [282]. Not a small variation existed in the numbers of infused cells and the administration frequencies. Although the overall study qualities did not surpass the level of moderate or poor, the results seemed promising in terms of MELD scores and liver function improvements [1]. Specifically, most studies did not include histologic evaluations [287].

As other kinds of MSCs, umbilical cord-derived MSCs (UC-MSCs) were evaluated in clinical trials. UC-MSC infusion was well tolerated and resulted in significant functional improvement and increased survival rates [288-290].

To summarize, stem cell trials in patients with liver cirrhosis have demonstrated generalized functional improvements. In addition, improvements were also found in the MELD and Child-Pugh scores. Unfortunately, these beneficial effects were attenuated with time or were not measured. Therefore, it can be temporarily concluded that treatment using stem cells might be slightly superior to current conventional treatment according to two systematic reviews $[1,42]$ (Table 1).

\section{Discussion}

Liver cirrhosis is a major cause of mortality and incurs great healthcare burdens across the world [291-294]. Liver transplantation is the only effective treatment. The survival rate after liver transplantation has progressively increased and the rate of survival after one year of surgery is currently $83 \%$ after one year. However, the shortage of organs is a serious problem contributing to the increasing mortality rate of patients on the waiting list $[295,296]$. Allogeneic hepatocyte transplantation $[297,298]$ also entails limited availability with only modest benefits reported [26, 299, 300].

Efforts have been made to develop antifibrotic therapies. Unfortunately, there are no antifibrotic drugs available in a current clinical setting [301-303] even if several reports have been published from preclinical and clinical studies [304306]. The targets of the drug are primarily associated with the activities of hepatic stellate cells: the downregulation of cell activation [307-310], neutralization of fibrogenic and proliferative cell responses [311-313], promotion of cell apoptosis [314], and promotion of matrix degradation $[315,316]$. Clinical studies have, however, failed to yield meaningful results compared with preclinical studies [287, 317-319].

In this regard, stem cell-based therapy is considered a promising therapeutic alternative based on the discrepancy between the demand and supply of donor livers for transplantation. Stem cell clinical trials have resulted in promising outcomes [20, 209, 230, 246, 277, 320-325]. There are advantages and disadvantages depending on which source of stem cells is used in the cell-based therapies. For example, ethical issues and behavioral uncertainties in vivo are major problems of ESCs or iPSCs to be used clinically although they are the most capability of producing HLCs [20]. Teratoma formation and the use of immunomodulatory drugs are other concerns of stem cell uses. For all kinds of stem cell-based therapies, the progressive liver fibrosis and hepatocellular carcinoma are still the fearful medium- or long-term adverse effects. Prior to clinical use, the in vivo safety should be confirmed including toxicity and tumorigenicity. Regulatory challenges and financial burden cast somewhat different kinds of translational barrier.

Among stem cells of various origins, MSCs have attracted attention due to their advantages and have been extensively investigated in experimental studies and in clinical trials. Nevertheless, there are still a number of issues to be addressed. First, the ideal delivery route of MSCs has not been elucidated, and it is unstandardized in clinical trials to date. MSCs differentiate into myofibroblasts instead of hepatocytes depending on the injection route [326, 327]. The optimal dose and number of injections are another practical issue when comparing the results from clinical trials. In addition, sophisticated methods of tracking engrafted MSCs are still lacking. Therefore, it is impossible to predict the fate of transplanted cells, although the survival duration is important for sustained efficacy [328-330]. Recently, labeling cells with superparamagnetic iron oxide nanoparticles and reporter genes have been suggested with advanced imaging technologies [331-336]. Finally, the quality of the clinical studies reported to date is far from sufficient to reach a definite conclusion. Patient enrollment must differentiate clearly between patients with compensated cirrhosis and patients with impaired function. Only randomized controlled designs can assess the reliable clinical benefit. Long-term follow-up and histologic evidence should be recommended in cases where they are available [42, 250, 337].

With advances in novel biotechnology, strategies have been devised to enhance the effects of stem cell-based therapy. For example, the microencapsulation of MSCs in microspheres was proposed to evade unwanted differentiation into myoblasts [338]. To promote the homing of MSCs, the use of MSCs modified by liver-specific receptors has been suggested [339]. Genome editing using CRISPR/Cas9 is a very promising technology widely used in current functional genomics [18, 340, 341]. The three-dimensional culture technique is another example for providing an expansion and differentiation platform for hepatocytes [342, 343].

Rapidly developing iPSC technologies provide an unprecedented opportunity for researchers and clinicians [344]. Recent studies have shown that iPSC-derived hepatocytes can be used for the investigation of the genetic and molecular mechanisms of liver disorders [240, 242, 244, 345356]. They can be utilized for multiple applications, including drug safety screening of new drugs [214, 357-359] and disease modeling [240, 360]. Disease-specific iPSCs could provide invaluable opportunities to elucidate the pathologic mechanism of disease and develop curative treatment options.

\section{Conclusion}

Liver fibrosis progresses to cirrhosis, which is the result of the extracellular matrix deposition in the parenchyma. Curative treatment for cirrhosis is currently limited to orthotopic liver transplantation, and a worldwide shortage of donor organs results in the deaths of patients waiting for organs. Stem cell-based therapy has emerged as a promising alternative with accumulating evidence from experimental and clinical 


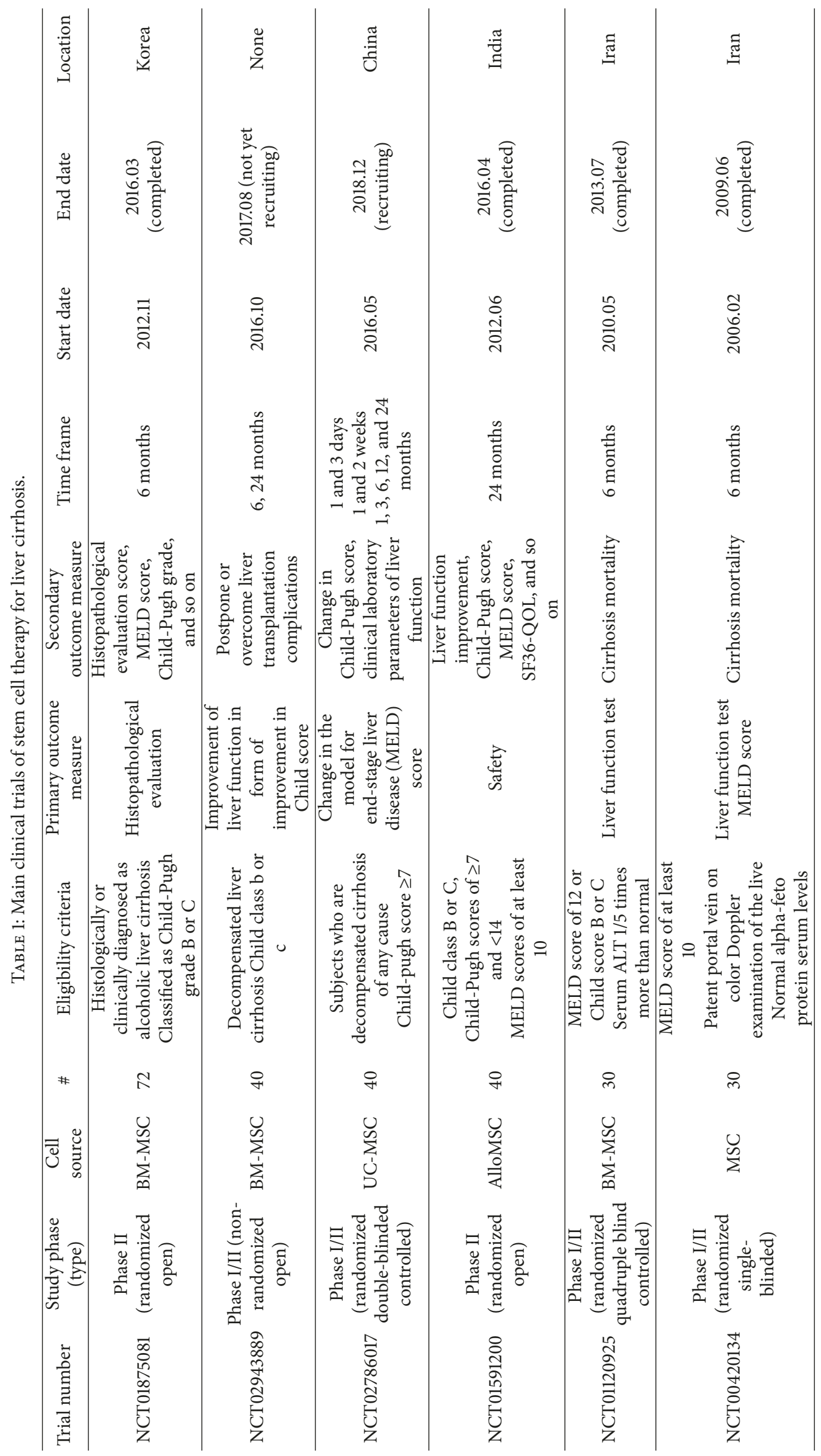




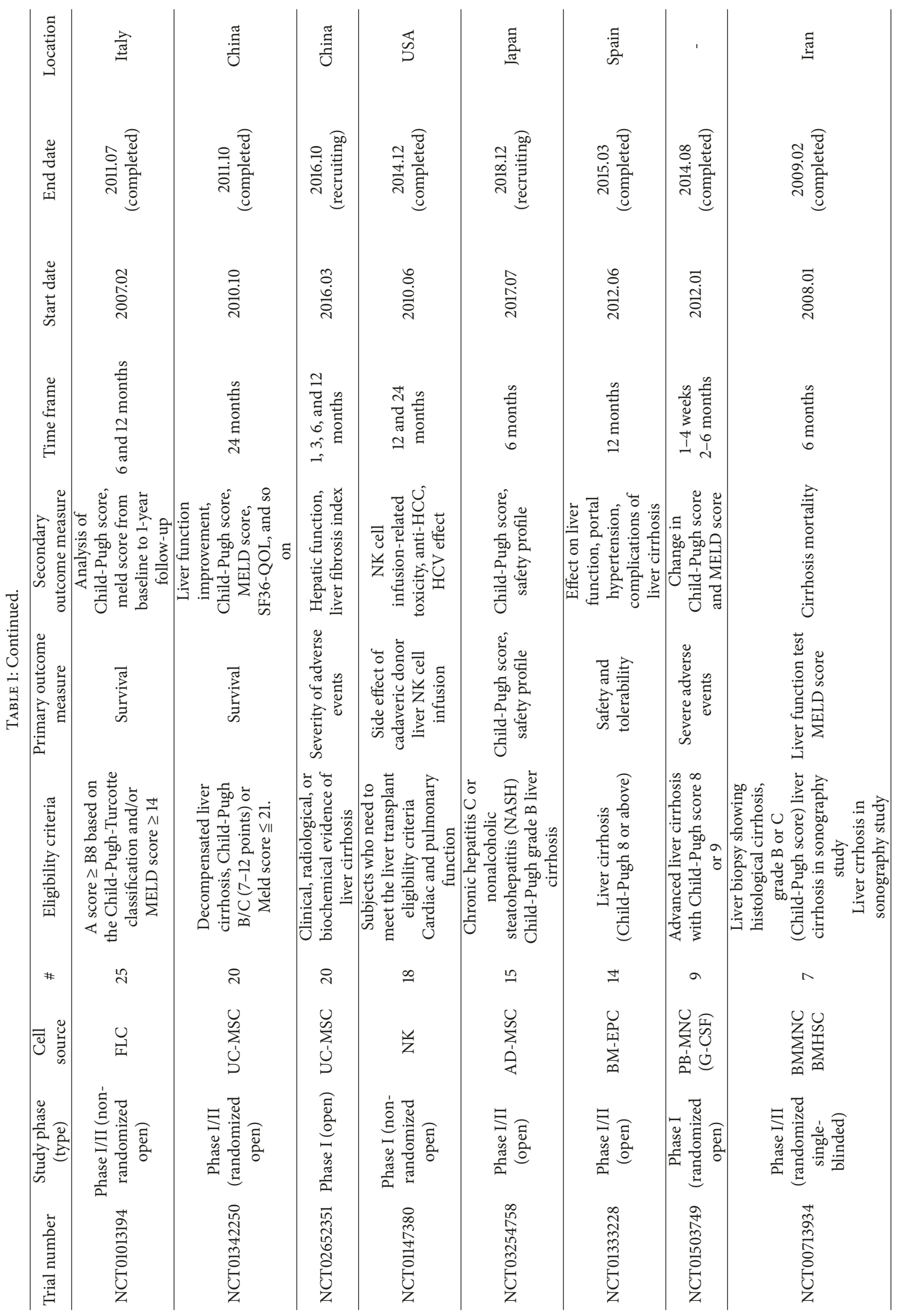




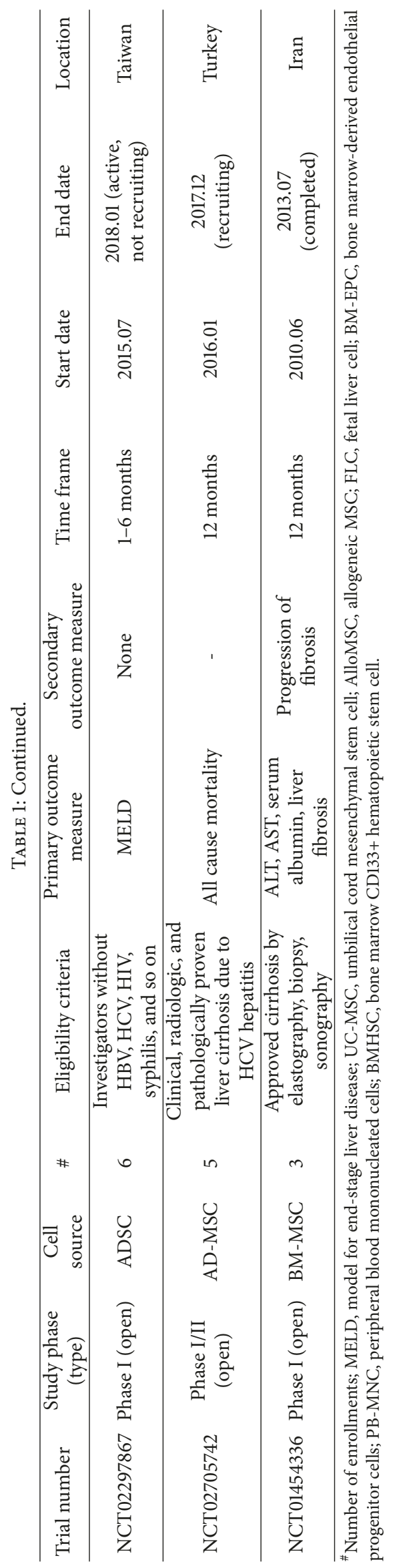


studies. Varieties of stem cells including MSCs, HSCs, EPCs, ESCs, and iPSCs have been investigated for their feasibility and/or clinical potentials. Among them, MSCs have been most studied and are relatively well understood. A primary mechanism of action has been proposed as paracrine effects rather than transdifferentiation. The results from clinical trials seem very promising from the perspectives of functional improvement and clinical parameters. However, longterm efficacy has not yet been proven, and standardized trial protocols are needed. Novel technologies are expected to overcome the current hurdles related to clinical application of stem cell-based therapy.

\section{Conflicts of Interest}

All authors have no conflicts of interest relevant to this article.

\section{Authors' Contributions}

Kyeong-Ah Kwak and Hyun-Jae Cho contributed equally to this work.

\section{Acknowledgments}

This research was supported by Ministry of Food and Drug Safety of Korea (Grant 17172MFDS202).

\section{References}

[1] Y. W. Eom, K. Y. Shim, and S. K. Baik, "Mesenchymal stem cell therapy for liver fibrosis," Korean Journal of Internal Medicine, vol. 30, no. 5, pp. 580-589, 2015.

[2] R. Bataller and D. A. Brenner, "Liver fibrosis," The Journal of Clinical Investigation, vol. 115, no. 2, pp. 209-218, 2005.

[3] R. Domitrović and H. Jakovac, "Effects of standardized bilberry fruit extract (Mirtoselect ${ }^{\circledR}$ ) on resolution of CCl4-induced liver fibrosis in mice," Food and Chemical Toxicology, vol. 49, no. 4, pp. 848-854, 2011.

[4] S. Ghatak, A. Biswas, G. K. Dhali, A. Chowdhury, J. L. Boyer, and A. Santra, "Oxidative stress and hepatic stellate cell activation are key events in arsenic induced liver fibrosis in mice," Toxicology and Applied Pharmacology, vol. 251, no. 1, pp. 59-69, 2011.

[5] W. K. Hong, M. Y. Kim, S. K. Baik et al., "The usefulness of noninvasive liver stiffness measurements in predicting clinically significant portal hypertension in cirrhotic patients: Korean data.," Clinical and Molecular Hepatology, vol. 19, no. 4, pp. 370375, 2013.

[6] T. Kisseleva and D. A. Brenner, "Mechanisms of fibrogenesis," Experimental Biology and Medicine, vol. 233, no. 2, pp. 109-122, 2008.

[7] H. Malhi and G. J. Gores, "Cellular and molecular mechanisms of liver injury," Gastroenterology, vol. 134, no. 6, pp. 1641-1654, 2008.

[8] K. M. Moon, G. Kim, S. K. Baik et al., "Ultrasonographic scoring system score versus liver stiffness measurement in prediction of cirrhosis.," Clinical and Molecular Hepatology, vol. 19, no. 4, pp. 389-398, 2013.
[9] V. K. Snowdon and J. A. Fallowfield, "Models and Mechanisms of Fibrosis Resolution," Alcoholism: Clinical and Experimental Research, vol. 35, no. 5, pp. 794-799, 2011.

[10] R. Lichtinghagen, D. Michels, C. I. Haberkorn et al., "Matrix metalloproteinase (MMP)-2, MMP-7, and tissue inhibitor of metalloproteinase- 1 are closely related to the fibroproliferative process in the liver during chronic hepatitis C," Journal of Hepatology, vol. 34, no. 2, pp. 239-247, 2001.

[11] A. El Taghdouini and L. A. van Grunsven, "Epigenetic regulation of hepatic stellate cell activation and liver fibrosis," Expert Review of Gastroenterology \& Hepatology, vol. 10, no. 12, pp. 1397-1408, 2016.

[12] A. El Taghdouini, A. L. Sørensen, A. H. Reiner et al., "Genomewide analysis of DNA methylation and gene expression patterns in purified, uncultured human liver cells and activated hepatic stellate cells," Oncotarget , vol. 6, no. 29, pp. 26729-26745, 2015.

[13] D. Schuppan and N. H. Afdhal, "Liver cirrhosis," The Lancet, vol. 371, no. 9615, pp. 838-851, 2008.

[14] H. R. Perez and J. H. Stoeckle, "Stuttering: clinical and research update," Can Fam Physician, vol. 62, pp. 479-484, 2016.

[15] N. Carbonell, A. Pauwels, L. Serfaty, O. Fourdan, V. G. Lévy, and R. Poupon, "Improved survival after variceal bleeding in patients with cirrhosis over the past two decades," Hepatology, vol. 40, no. 3, pp. 652-659, 2004.

[16] K. Stokkeland, L. Brandt, A. Ekbom, and R. Hultcrantz, "Improved prognosis for patients hospitalized with esophageal varices in Sweden 1969-2002," Hepatology, vol. 43, no. 3, pp. 500-505, 2006.

[17] R. Lozano, M. Naghavi, K. Foreman et al., "Global and regional mortality from 235 causes of death for 20 age groups in 1990 and 2010: A systematic analysis for the Global Burden of Disease Study 2010," The Lancet, vol. 380, no. 9859, pp. 2095-2128, 2012.

[18] Y. Guo, B. Chen, L.-J. Chen, C.-F. Zhang, and C. Xiang, "Current status and future prospects of mesenchymal stem cell therapy for liver fibrosis," Journal of Zhejiang University SCIENCE B, vol. 17, no. 11, pp. 831-841, 2016.

[19] J. W. Kung and S. J. Forbes, "Stem cells and liver repair," Current Opinion in Biotechnology, vol. 20, no. 5, pp. 568-574, 2009.

[20] Z. Zhang and F.-S. Wang, "Stem cell therapies for liver failure and cirrhosis," Journal of Hepatology, vol. 59, no. 1, pp. 183-185, 2013.

[21] T. G. Bird, S. Lorenzini, and S. J. Forbes, "Activation of stem cells in hepatic diseases," Cell and Tissue Research, vol. 331, no. 1, pp. 283-300, 2008.

[22] Y. Y. Dan and G. C. Yeoh, "Liver stem cells: A scientific and clinical perspective," Journal of Gastroenterology and Hepatology, vol. 23, no. 5, pp. 687-698, 2008.

[23] V. Papp, A. Rókusz, K. Dezso et al., "Expansion of hepatic stem cell compartment boosts liver regeneration," Stem Cells and Development, vol. 23, no. 1, pp. 56-65, 2014.

[24] N. Fausto, J. S. Campbell, and K. J. Riehle, "Liver regeneration," Hepatology, vol. 43, no. 2, pp. S45-S53, 2006.

[25] G. K. Michalopoulos and M. C. DeFrances, "Liver regeneration," Science, vol. 276, no. 5309, pp. 60-65, 1997.

[26] R. Gramignoli, M. Vosough, K. Kannisto, R. C. Srinivasan, and S. C. Strom, "Clinical hepatocyte transplantation: practical limits and possible solutions," European Surgical Research, vol. 54, no. 3-4, pp. 162-177, 2015.

[27] M. Najimi and E. Sokal, "Liver cell transplantation," Minerva Pediatrica, vol. 57, no. 5, pp. 243-257, 2005. 
[28] S. C. Strom, J. R. Chowdhury, and I. J. Fox, "Hepatocyte transplantation for the treatment of human disease," Seminars in Liver Disease, vol. 19, no. 1, pp. 39-48, 1999.

[29] J. Puppi, S. C. Strom, R. D. Hughes et al., "Improving the techniques for human hepatocyte transplantation: Report from a consensus meeting in London," Cell Transplantation, vol. 21, no. 1, pp. 1-10, 2012.

[30] K. A. Soltys, A. Soto-Gutiérrez, M. Nagaya et al., "Barriers to the successful treatment of liver disease by hepatocyte transplantation," Journal of Hepatology, vol. 53, no. 4, pp. 769774,2010

[31] S. Terai, T. Ishikawa, K. Omori et al., "Improved liver function in patients with liver cirrhosis after autologous bone marrow cell infusion therapy," Stem Cells, vol. 24, no. 10, pp. 2292-2298, 2006.

[32] S. Terai, H. Tanimoto, M. Maeda et al., "Timeline for development of autologous bone marrow infusion (ABMi) therapy and perspective for future stem cell therapy," Journal of Gastroenterology, vol. 47, no. 5, pp. 491-497, 2012.

[33] K.-A. Cho, G.-W. Lim, S.-Y. Joo et al., "Transplantation of bone marrow cells reduces CCl 4-induced liver fibrosis in mice," Liver International, vol. 31, no. 7, pp. 932-939, 2011.

[34] A. Gasbarrini, G. L. Rapaccini, S. Rutella et al., "Rescue therapy by portal infusion of autologous stem cells in a case of druginduced hepatitis," Digestive and Liver Disease, vol. 39, no. 9, pp. 878-882, 2007.

[35] P. Kharaziha, P. M. Hellström, B. Noorinayer et al., "Improvement of liver function in liver cirrhosis patients after autologous mesenchymal stem cell injection: a phase I-II clinical trial," European Journal of Gastroenterology \& Hepatology, vol. 21, no. 10, pp. 1199-1205, 2009.

[36] N. Levičar, M. Pai, N. A. Habib et al., "Long-term clinical results of autologous infusion of mobilized adult bone marrow derived CD34 + cells in patients with chronic liver disease," Cell Proliferation, vol. 41, no. 1, pp. 115-125, 2008.

[37] M. Pai, D. Zacharoulis, M. N. Milicevic et al., "Autologous infusion of expanded mobilized adult bone marrow-derived CD34+ cells into patients with alcoholic liver cirrhosis," American Journal of Gastroenterology, vol. 103, no. 8, pp. 1952-1958, 2008.

[38] I. Sakaida, S. Terai, N. Yamamoto et al., "Transplantation of bone marrow cells reduces $\mathrm{CCl}_{4}$-induced liver fibrosis in mice," Hepatology, vol. 40, no. 6, pp. 1304-1311, 2004.

[39] M. R. Alison, S. Islam, and S. M. L. Lim, "Cell therapy for liver disease," Current Opinion in Molecular Therapeutics, vol. 11, no. 4, pp. 364-374, 2009.

[40] A. G. Bonavita, K. Quaresma, V. Cotta-De-Almeida, M. A. Pinto, R. M. Saraiva, and L. A. Alves, "Hepatocyte xenotransplantation for treating liver disease: Review Article," Xenotransplantation, vol. 17, no. 3, pp. 181-187, 2010.

[41] S. M. Park, "Stem cell research in gastroenterology", The Korean journal of gastroenterology = Taehan Sohwagi Hakhoe chi, vol. 43, no. 4, pp. 221-225, 2004.

[42] X. Qi, X. Guo, and C. Su, "Clinical outcomes of the transplantation of stem cells from various human tissue sources in the management of Liver Cirrhosis: A systematic review and metaanalysis," Current Stem Cell Research \& Therapy, vol. 10, no. 2, pp. 166-180, 2015.

[43] E. Y. Shevela, N. M. Starostina, A. I. Pal'tsev et al., "Efficiency of Cell Therapy in Liver Cirrhosis," Bulletin of Experimental Biology and Medicine, vol. 160, no. 4, pp. 542-547, 2016.
[44] M. R. Alison, R. Poulsom, R. Jeffery et al., "Hepatocytes from non-hepatic adult stem cells," Nature, vol. 406, no. 6793, p. 257, 2000.

[45] N. D. Theise, M. Nimmakayalu, R. Gardner et al., "Liver from bone marrow in humans," Hepatology, vol. 32 , no. 1, pp. 11-16, 2000.

[46] J. M. Vainshtein, R. Kabarriti, K. J. Mehta, J. Roy-Chowdhury, and C. Guha, "Bone marrow-derived stromal cell therapy in cirrhosis: Clinical evidence, cellular mechanisms, and implications for the treatment of Hepatocellular carcinoma," International Journal of Radiation Oncology • Biology • Physics, vol. 89, no. 4, pp. 786-803, 2014.

[47] M.-E. M. Amer, S. Z. El-Sayed, W. A. El-Kheir et al., "Clinical and laboratory evaluation of patients with end-stage liver cell failure injected with bone marrow-derived hepatocyte-like cells," European Journal of Gastroenterology \& Hepatology, vol. 23, no. 10, pp. 936-941, 2011.

[48] A. C. Lyra, M. B. P. Soares, L. F. M. da Silva et al., "Infusion of autologous bone marrow mononuclear cells through hepatic artery results in a short-term improvement of liver function in patients with chronic liver disease: a pilot randomized controlled study," European Journal of Gastroenterology \& Hepatology, vol. 22, no. 1, pp. 33-42, 2010.

[49] A. C. Lyra, M. B. Pereira Soares, L. F. Maia da Silva et al., "Feasiblity and safety of autologous bone marrow mononuclear cell transplantation in patients with advanced chronic liver disease," World Journal of Gastroenterology, vol. 13, no. 7, pp. 1067-1073, 2007.

[50] T. Saito, K. Okumoto, H. Haga et al., "Potential therapeutic application of intravenous autologous bone marrow infusion in patients with alcoholic liver cirrhosis," Stem Cells and Development, vol. 20, no. 9, pp. 1503-1510, 2011.

[51] T. Takami, S. Terai, and I. Sakaida, "Stem cell therapy in chronic liver disease," Current Opinion in Gastroenterology, vol. 28, no. 3, pp. 203-208, 2012.

[52] S. Terai, T. Takami, N. Yamamoto et al., "Status and prospects of liver cirrhosis treatment by using bone marrow-derived cells and mesenchymal cells," Tissue Engineering - Part B: Reviews, vol. 20, no. 3, pp. 206-210, 2014.

[53] M. T. Abdel Aziz, H. M. Atta, S. Mahfouz et al., "Therapeutic potential of bone marrow-derived mesenchymal stem cells on experimental liver fibrosis," Clinical Biochemistry, vol. 40, no. 12, pp. 893-899, 2007.

[54] B. Fang, M. Shi, L. Liao, S. Yang, Y. Liu, and R. C. Zhao, "Systemic infusion of FLK1+ mesenchymal stem cells ameliorate carbon tetrachloride-induced liver fibrosis in mice," Transplantation, vol. 78, no. 1, pp. 83-88, 2004.

[55] T. Nakamura, T. Torimura, M. Sakamoto et al., "Significance and Therapeutic Potential of Endothelial Progenitor Cell Transplantation in a Cirrhotic Liver Rat Model," Gastroenterology, vol. 133, no. 1, pp. 91-el, 2007.

[56] S. Oyagi, M. Hirose, M. Kojima et al., "Therapeutic effect of transplanting HGF-treated bone marrow mesenchymal cells into CCl4-injured rats," Journal of Hepatology, vol. 44, no. 4, pp. 742-748, 2006.

[57] Y. Zhan, Y. Wang, L. Wei et al., "Differentiation of Hematopoietic Stem Cells into Hepatocytes in Liver Fibrosis in Rats," Transplantation Proceedings, vol. 38, no. 9, pp. 3082-3085, 2006.

[58] R. Kia, R. L. C. Sison, J. Heslop et al., "Stem cell-derived hepatocytes as a predictive model for drug-induced liver injury: are we there yet?" British Journal of Clinical Pharmacology, vol. 75, no. 4, pp. 885-896, 2013. 
[59] S.-N. Shu, L. Wei, J.-H. Wang, Y.-T. Zhan, H.-S. Chen, and Y. Wang, "Hepatic differentiation capability of rat bone marrowderived mesenchymal stem cells and hematopoietic stem cells," World Journal of Gastroenterology, vol. 10, no. 19, pp. 2818-2822, 2004.

[60] K. Si-Tayeb, F. K. Noto, M. Nagaoka et al., "Highly efficient generation of human hepatocyte-like cells from induced pluripotent stem cells," Hepatology, vol. 51, no. 1, pp. 297-305, 2010.

[61] Y. W. Eom, G. Kim, and S. K. Baik, "Mesenchymal stem cell therapy for cirrhosis: Present and future perspectives," World Journal of Gastroenterology, vol. 21, no. 36, pp. 10253-10261, 2015.

[62] T. R. Brazelton, F. M. V. Rossi, G. I. Keshet, and H. M. Blau, "From marrow to brain: expression of neuronal phenotypes in adult mice," Science, vol. 290, no. 5497, pp. 1775-1779, 2000.

[63] G. Ferrari, G. Cusella-De Angelis, M. Coletta et al., "Muscle regeneration by bone marrow-derived myogenic progenitors," Science, vol. 279, no. 5356, pp. 1528-1530, 1998.

[64] A. Ianus, G. G. Holz, N. D. Theise, and M. A. Hussain, "In vivo derivation of glucose-competent pancreatic endocrine cells from bone marrow without evidence of cell fusion," The Journal of Clinical Investigation, vol. 111, no. 6, pp. 843-850, 2003.

[65] E. Lagasse, H. Connors, M. Al-Dhalimy et al., "Purified hematopoietic stem cells can differentiate into hepatocytes in vivo," Nature Medicine, vol. 6, no. 11, pp. 1229-1234, 2000.

[66] D. Orlic, J. Kajstura, S. Chimenti et al., "Bone marrow cells regenerate infarcted myocardium," Nature, vol. 410, no. 6829, pp. 701-705, 2001.

[67] B. E. Petersen, W. C. Bowen, K. D. Patrene et al., "Bone marrow as a potential source of hepatic oval cells," Science, vol. 284, no. 5417, pp. 1168-1170, 1999.

[68] R. E. Schwartz, M. Reyes, L. Koodie et al., "Multipotent adult progenitor cells from bone marrow differentiate into functional hepatocyte-like cells," The Journal of Clinical Investigation, vol. 109, no. 10, pp. 1291-1302, 2002.

[69] S. Hombach-Klonisch, S. Panigrahi, I. Rashedi et al., "Adult stem cells and their trans-differentiation potential - Perspectives and therapeutic applications," Journal of Molecular Medicine, vol. 86, no. 12, pp. 1301-1314, 2008.

[70] G. Menichella, M. Lai, R. Serafini et al., "Large volume leukapheresis for collecting hemopoietic progenitors: Role of CD 34+ precount in predicting successful collection," The International Journal of Artificial Organs, vol. 22, no. 5, pp. 334-341, 1999.

[71] G. De Silvestro, M. Vicarioto, C. Donadel, M. Menegazzo, P. Marson, and A. Corsini, "Mobilization of peripheral blood hematopoietic stem cells following liver resection surgery," Hepato-Gastroenterology, vol. 51, no. 57, pp. 805-810, 2004.

[72] R. M. Lemoli, L. Catani, S. Talarico et al., "Mobilization of bone marrow-derived hematopoietic and endothelial stem cells after orthotopic liver transplantation and liver resection," Stem Cells, vol. 24, no. 12, pp. 2817-2825, 2006.

[73] M. Mohty and A. D. Ho, "In and out of the niche: perspectives in mobilization of hematopoietic stem cells," Experimental Hematology, vol. 39, no. 7, pp. 723-729, 2011.

[74] L. B. To, D. N. Haylock, P. J. Simmons, and C. A. Juttner, "The biology and clinical uses of blood stem cells," Blood, vol. 89, no. 7, pp. 2233-2258, 1997.

[75] D. Metcalf, "The molecular control of cell division, differentiation commitment and maturation in haemopoietic cells," Nature, vol. 339, no. 6219, pp. 27-30, 1989.
[76] A. C. Piscaglia, T. D. Shupe, S.-H. Oh, A. Gasbarrini, and B. E. Petersen, "Granulocyte-Colony Stimulating Factor Promotes Liver Repair and Induces Oval Cell Migration and Proliferation in Rats," Gastroenterology, vol. 133, no. 2, pp. 619-631, 2007.

[77] O. Quintana-Bustamante, A. Alvarez-Barrientos, A. V. Kofman et al., "Hematopoietic mobilization in mice increases the presence of bone marrow-derived hepatocytes via in vivo cell fusion," Hepatology, vol. 43, no. 1, pp. 108-116, 2006.

[78] E. Tsolaki, E. Athanasiou, E. Gounari et al., "Hematopoietic stem cells and liver regeneration: Differentially acting hematopoietic stem cell mobilization agents reverse induced chronic liver injury," Blood Cells, Molecules, and Diseases, vol. 53, no. 3, pp. 124-132, 2014.

[79] E. Yannaki, E. Athanasiou, A. Xagorari et al., "G-CSF-primed hematopoietic stem cells or G-CSF per se accelerate recovery and improve survival after liver injury, predominantly by promoting endogenous repair programs," Experimental Hematology, vol. 33, no. 1, pp. 108-119, 2005.

[80] E. Tsolaki and E. Yannaki, "Stem cell-based regenerative opportunities for the liver: State of the art and beyond," World Journal of Gastroenterology, vol. 21, no. 43, pp. 12334-12350, 2015.

[81] Y.-Y. Jang, M. I. Collector, S. B. Baylin, A. M. Diehl, and S. J. Sharkis, "Hematopoietic stem cells convert into liver cells within days without fusion," Nature Cell Biology, vol. 6, no. 6, pp. 532-539, 2004.

[82] S. Khurana and A. Mukhopadhyay, "Characterization of the potential subpopulation of bone marrow cells involved in the repair of injured liver tissue," Stem Cells, vol. 25, no. 6, pp. 14391447, 2007.

[83] N. D. Theise, S. Badve, R. Saxena et al., "Derivation of hepatocytes from bone marrow cells in mice after radiation-induced myeloablation," Hepatology, vol. 31, no. 1, pp. 235-240, 2000.

[84] T. W. Austin and E. Lagasse, "Hepatic regeneration from hematopoietic stem cells," Mechanisms of Development, vol. 120, no. 1, pp. 131-135, 2003.

[85] T. Kisseleva and D. A. Brenner, "The phenotypic fate and functional role for bone marrow-derived stem cells in liver fibrosis," Journal of Hepatology, vol. 56, no. 4, pp. 965-972, 2012.

[86] S. S. Thorgeirsson and J. W. Grisham, "Hematopoietic cells as hepatocyte stem cells: a critical review of the evidence," Hepatology, vol. 43, no. 1, pp. 2-8, 2006.

[87] J. A. Thomas, C. Pope, D. Wojtacha et al., "Macrophage therapy for murine liver fibrosis recruits host effector cells improving fibrosis, regeneration, and function," Hepatology, vol. 53, no. 6, pp. 2003-2015, 2011.

[88] L. Boulter, O. Govaere, T. G. Bird et al., "Macrophage-derived Wnt opposes Notch signaling to specify hepatic progenitor cell fate in chronic liver disease," Nature Medicine, vol. 18, no. 4, pp. 572-579, 2012.

[89] X. Aldeguer, F. Debonera, A. Shaked et al., "Interleukin-6 from intrahepatic cells of bone marrow origin is required for normal murine liver regeneration," Hepatology, vol. 35, no. 1, pp. 40-48, 2002.

[90] F. S. Loffredo, M. L. Steinhauser, J. Gannon, and R. T. Lee, "Bone marrow-derived cell therapy stimulates endogenous cardiomyocyte progenitors and promotes cardiac repair," Cell Stem Cell, vol. 8, no. 4, pp. 389-398, 2011.

[91] X. L. Tang, G. Rokosh, S. K. Sanganalmath et al., "Intracoronary administration of cardiac progenitor cells alleviates left ventricular dysfunction in rats with a 30-day-old infarction," Circulation, vol. 121, no. 2, pp. 293-305, 2010. 
[92] B. Larrivee and A. Karsan, "Involvement of marrow-derived endothelial cells in vascularization," Handbook of Experimental Pharmacology, pp. 89-114, 2007.

[93] T. Asahara, H. Masuda, T. Takahashi et al., "Bone marrow origin of endothelial progenitor cells responsible for postnatal vasculogenesis in physiological and pathological neovascularization," Circulation Research, vol. 85, no. 3, pp. 221-228, 1999.

[94] T. Asahara, T. Murohara, A. Sullivan et al., "Isolation of putative progenitor endothelial cells for angiogenesis," Science, vol. 275, no. 5302, pp. 964-967, 1997.

[95] T. Asahara, T. Takahashi, H. Masuda et al., "VEGF contributes to postnatal neovascularization by mobilizing bone marrowderived endothelial progenitor cells," EMBO Journal, vol. 18, no. 14, pp. 3964-3972, 1999.

[96] C. Kalka, H. Masuda, T. Takahashi et al., "Transplantation of ex vivo expanded endothelial progenitor cells for therapeutic neovascularization," Proceedings of the National Acadamy of Sciences of the United States of America, vol. 97, no. 7, pp. 3422$3427,2000$.

[97] A. Kawamoto, H.-C. Gwon, H. Iwaguro et al., "Therapeutic potential of ex vivo expanded endothelial progenitor cells for myocardial ischemia," Circulation, vol. 103, no. 5, pp. 634-637, 2001.

[98] T. Takahashi, C. Kalka, H. Masuda et al., "Ischemia- and cytokine-induced mobilization of bone marrow-derived endothelial progenitor cells for neovascularization," Nature Medicine, vol. 5, no. 4, pp. 434-438, 1999.

[99] J.-I. Yamaguchi, K. F. Kusano, O. Masuo et al., "Stromal cell-derived factor-1 effects on ex vivo expanded endothelial progenitor cell recruitment for ischemic neovascularization," Circulation, vol. 107, no. 9, pp. 1322-1328, 2003.

[100] T. Asahara and A. Kawamoto, "Endothelial progenitor cells for postnatal vasculogenesis," American Journal of Physiology-Cell Physiology, vol. 287, no. 3, pp. C572-C579, 2004.

[101] A. S. Bailey, S. Jiang, M. Afentoulis et al., "Transplanted adult hematopoietic stems cells differentiate into functional endothelial cells," Blood, vol. 103, no. 1, pp. 13-19, 2004.

[102] K. Choi, M. Kennedy, A. Kazarov, J. C. Papadimitriou, and G. Keller, "A common precursor for hematopoietic and endothelial cells," Development, vol. 125, no. 4, pp. 725-732, 1998.

[103] E. Pelosi, M. Valtieri, S. Coppola et al., "Identification of the hemangioblast in postnatal life," Blood, vol. 100, no. 9, pp. 3203$3208,2002$.

[104] D. Ribatti, “The discovery of endothelial progenitor cells. An historical review," Leukemia Research, vol. 31, no. 4, pp. 439444, 2007.

[105] Q. Shi, S. Rafii, M. Wu Hong-De et al., "Evidence for circulating bone marrow-derived endothelial cells," Blood, vol. 92, no. 2, pp. 362-367, 1998.

[106] C. Urbich and S. Dimmeler, "Endothelial progenitor cells: functional characterization," Trends in Cardiovascular Medicine, vol. 14, no. 8, pp. 318-322, 2004.

[107] A. Al-Khaldi, N. Eliopoulos, D. Martineau, L. Lejeune, K. Lachapelle, and J. Galipeau, "Postnatal bone marrow stromal cells elicit a potent VEGF-dependent neoangiogenic response in vivo," Gene Therapy, vol. 10, no. 8, pp. 621-629, 2003.

[108] A. P. Beltrami, L. Barlucchi, D. Torella et al., "Adult cardiac stem cells are multipotent and support myocardial regeneration," Cell, vol. 114, no. 6, pp. 763-776, 2003.
[109] B. Dome, J. Dobos, J. Tovari et al., "Circulating bone marrowderived endothelial progenitor cells: characterization, mobilization, and therapeutic considerations in malignant disease," Cytometry Part A, vol. 73, no. 3, pp. 186-193, 2008.

[110] N. Kubis, Y. Tomita, A. Tran-Dinh et al., "Vascular fate of adipose tissue-derived adult stromal cells in the ischemic murine brain: A combined imaging-histological study," NeuroImage, vol. 34, no. 1, pp. 1-11, 2007.

[111] A. Miranville, C. Heeschen, C. Sengenès, C. A. Curat, R. Busse, and A. Bouloumié, "Improvement of postnatal neovascularization by human adipose tissue-derived stem cells," Circulation, vol. 110, no. 3, pp. 349-355, 2004.

[112] V. Planat-Benard, J.-S. Silvestre, B. Cousin et al., "Plasticity of human adipose lineage cells toward endothelial cells: physiological and therapeutic perspectives," Circulation, vol. 109, no. 5, pp. 656-663, 2004.

[113] A. E. Wurmser, K. Nakashima, R. G. Summers et al., "Cell fusion-independent differentiation of neural stem cells to the endothelial lineage," Nature, vol. 430, no. 6997, pp. 350-356, 2004.

[114] L. Wang, X. Wang, G. Xie, L. Wang, C. K. Hill, and L. D. DeLeve, "Liver sinusoidal endothelial cell progenitor cells promote liver regeneration in rats," The Journal of Clinical Investigation, vol. 122, no. 4, pp. 1567-1573, 2012.

[115] P. Beaudry, Y. Hida, T. Udagawa et al., "Endothelial progenitor cells contribute to accelerated liver regeneration," Journal of Pediatric Surgery, vol. 42, no. 7, pp. 1190-1198, 2007.

[116] E. Taniguchi, M. Kin, T. Torimura et al., "Endothelial progenitor cell transplantation improves the survival following liver injury in mice," Gastroenterology, vol. 130, no. 2, pp. 521-531, 2006.

[117] T. Ueno, T. Nakamura, T. Torimura, and M. Sata, "Angiogenic cell therapy for hepatic fibrosis," Medical Molecular Morphology, vol. 39, no. 1, pp. 16-21, 2006.

[118] K. Fukuda and J. Fujita, "Mesenchymal, but not hematopoietic, stem cells can be mobilized and differentiate into cardiomyocytes after myocardial infarction in mice," Kidney International, vol. 68, no. 5, pp. 1940-1943, 2005.

[119] K. K. Hirschi and M. A. Goodell, "Hematopoietic, vascular and cardiac fates of bone marrow-derived stem cells," Gene Therapy, vol. 9, no. 10, pp. 648-652, 2002.

[120] Y. Jiang, B. N. Jahagirdar, R. L. Reinhardt et al., "Pluripotency of mesenchymal stem cells derived from adult marrow," Nature, vol. 418, no. 6893, pp. 41-49, 2002.

[121] Y. N. Kallis, M. R. Alison, and S. J. Forbes, "Bone marrow stem cells and liver disease," Gut, vol. 56, no. 5, pp. 716-724, 2007.

[122] G. Keilhoff, A. Goihl, K. Langnäse, H. Fansa, and G. Wolf, "Transdifferentiation of mesenchymal stem cells into Schwann cell-like myelinating cells," European Journal of Cell Biology, vol. 85, no. 1, pp. 11-24, 2006.

[123] C. Krabbe, J. Zimmer, and M. Meyer, "Neural transdifferentiation of mesenchymal stem cells - A critical review," APMIS-Acta Pathologica, Microbiologica et Immunologica Scandinavica, vol. 113, no. 11-12, pp. 831-844, 2005.

[124] S. Masson, D. J. Harrison, J. N. Plevris, and P. N. Newsome, "Potential of hematopoietic stem cell therapy in hepatology: A critical review," Stem Cells, vol. 22, no. 6, pp. 897-907, 2004.

[125] M. F. Pittenger, J. D. Mosca, and K. R. McIntosh, "Human Mesenchymal Stem Cells: Progenitor Cells for Cartilage, Bone, Fat and Stroma," in Lymphoid Organogenesis, vol. 251 of Current Topics in Microbiology and Immunology, pp. 3-11, Springer Berlin Heidelberg, Berlin, Heidelberg, 2000. 
[126] W. S. N. Shim, S. Jiang, P. Wong et al., "Ex vivo differentiation of human adult bone marrow stem cells into cardiomyocyte-like cells," Biochemical and Biophysical Research Communications, vol. 324, no. 2, pp. 481-488, 2004.

[127] L. Song and R. S. Tuan, "Transdifferentiation potential of human mesenchymal stem cells derived from bone marrow," The FASEB Journal, vol. 18, no. 9, pp. 980-982, 2004.

[128] C. Toma, M. F. Pittenger, K. S. Cahill, B. J. Byrne, and P. D. Kessler, "Human mesenchymal stem cells differentiate to a cardiomyocyte phenotype in the adult murine heart," Circulation, vol. 105, no. 1, pp. 93-98, 2002.

[129] M. F. Pittenger, A. M. Mackay, S. C. Beck et al., "Multilineage potential of adult human mesenchymal stem cells," Science, vol. 284, no. 5411, pp. 143-147, 1999.

[130] C. De Bari, F. Dell'Accio, P. Tylzanowski, and F. P. Luyten, "Multipotent mesenchymal stem cells from adult human synovial membrane," Arthritis \& Rheumatology, vol. 44, no. 8, pp. 19281942, 2001.

[131] P. S. In’t Anker, S. A. Scherjon, C. Kleijburg-van der Keur et al., "Isolation of mesenchymal stem cells of fetal or maternal origin from human placenta," Stem Cells, vol. 22, no. 7, pp. 1338-1345, 2004.

[132] P. S. In't Anker, W. A. Noort, S. A. Scherjon et al., "Mesenchymal stem cells in human second-trimester bone marrow, liver, lung, and spleen exhibit a similar immunophenotype but a heterogeneous multilineage differentiation potential," Haematologica, vol. 88, no. 8, pp. 845-852, 2003.

[133] P. S. In 't Anker, S. A. Scherjon, C. Kleijburg-van der Keur et al., "Amniotic fluid as a novel source of mesenchymal stem cells for therapeutic transplantation," Blood, vol. 102, no. 4, pp. 15481549, 2003.

[134] Y. Jiang, B. Vaessen, T. Lenvik, M. Blackstad, M. Reyes, and C. M. Verfaillie, "Multipotent progenitor cells can be isolated from postnatal murine bone marrow, muscle, and brain," Experimental Hematology, vol. 30, no. 8, pp. 896-904, 2002.

[135] V. Sottile, C. Halleux, F. Bassilana, H. Keller, and K. Seuwen, "Stem cell characteristics of human trabecular bone-derived cells," Bone, vol. 30, no. 5, pp. 699-704, 2002.

[136] O. K. Lee, T. K. Kuo, W. M. Chen, K. D. Lee, S. L. Hsieh, and T. H. Chen, "Isolation of multipotent mesenchymal stem cells from umbilical cord blood," Blood, vol. 103, no. 5, pp. 1669-1675, 2004.

[137] P. A. Zuk, M. Zhu, P. Ashjian et al., "Human adipose tissue is a source of multipotent stem cells," Molecular Biology of the Cell (MBoC), vol. 13, no. 12, pp. 4279-4295, 2002.

[138] C. Campagnoli, I. A. G. Roberts, S. Kumar, P. R. Bennett, I. Bellantuono, and N. M. Fisk, "Identification of mesenchymal stem/progenitor cells in human first-trimester fetal blood, liver, and bone marrow," Blood, vol. 98, no. 8, pp. 2396-2402, 2001.

[139] D. A. de Ugarte, K. Morizono, A. Elbarbary et al., "Comparison of multi-lineage cells from human adipose tissue and bone marrow," Cells Tissues Organs, vol. 174, no. 3, pp. 101-109, 2003.

[140] A. Erices, P. Conget, and J. J. Minguell, "Mesenchymal progenitor cells in human umbilical cord blood," British Journal of Haematology, vol. 109, no. 1, pp. 235-242, 2000.

[141] N. J. Zvaifler, L. Marinova-Mutafchieva, G. Adams et al., "Mesenchymal precursor cells in the blood of normal individuals," Arthritis Research \& Therapy, vol. 2, no. 6, pp. 477-488, 2000.

[142] M. D. Kim, S. S. Kim, H. Y. Cha et al., "Therapeutic effect of hepatocyte growth factor-secreting mesenchymal stem cells in a rat model of liver fibrosis," Experimental \& molecular medicine, vol. 46, p. el10, 2014.
[143] B. M. Manzini, A. da Silva Santos Duarte, S. Sankaramanivel et al., "Useful properties of undifferentiated mesenchymal stromal cells and adipose tissue as the source in liver-regenerative therapy studied in an animal model of severe acute fulminant hepatitis," Cytotherapy, vol. 17, no. 8, pp. 1052-1065, 2015.

[144] M. Sundin, O. Ringdén, B. Sundberg, S. Nava, C. Götherström, and K. Le Blanc, "No alloantibodies against mesenchymal stromal cells, but presence of anti-fetal calf serum antibodies, after transplantation in allogeneic hematopoietic stem cell recipients," Haematologica, vol. 92, no. 9, pp. 1208-1215, 2007.

[145] S. Asari, S. Itakura, K. Ferreri et al., "Mesenchymal stem cells suppress B-cell terminal differentiation," Experimental Hematology, vol. 37, no. 5, pp. 604-615, 2009.

[146] A. Corcione, F. Benvenuto, E. Ferretti et al., "Human mesenchymal stem cells modulate B-cell functions," Blood, vol. 107, no. 1, pp. 367-372, 2006.

[147] W. Zhang, W. Ge, C. Li et al., "Effects of mesenchymal stem cells on differentiation, maturation, and function of human monocyte-derived dendritic cells," Stem Cells and Development, vol. 13, no. 3, pp. 263-271, 2004.

[148] B. Zhang, R. Liu, D. Shi et al., "Mesenchymal stem cells induce mature dendritic cells into a novel Jagged-2 dependent regulatory dendritic cell population," Blood, vol. 113, no. 1, pp. 46-57, 2009.

[149] G. M. Spaggiari, A. Capobianco, S. Becchetti, M. C. Mingari, and L. Moretta, "Mesenchymal stem cell-natural killer cell interactions: evidence that activated NK cells are capable of killing MSCs, whereas MSCs can inhibit IL-2-induced NK-cell proliferation," Blood, vol. 107, no. 4, pp. 1484-1490, 2006.

[150] S. Aggarwal and M. F. Pittenger, "Human mesenchymal stem cells modulate allogeneic immune cell responses," Blood, vol. 105, no. 4, pp. 1815-1822, 2005.

[151] H. Cao, J. Yang, J. Yu et al., "Therapeutic potential of transplanted placental mesenchymal stem cells in treating Chinese miniature pigs with acute liver failure," BMC Medicine, vol. 10, article 56, 2012.

[152] K. English, J. M. Ryan, L. Tobin, M. J. Murphy, F. P. Barry, and B. P. Mahon, "Cell contact, prostaglandin E2 and transforming growth factor beta 1 play non-redundant roles in human mesenchymal stem cell induction of CD4+CD25Highforkhead box P3+ regulatory T cells," Clinical \& Experimental Immunology, vol. 156, no. 1, pp. 149-160, 2009.

[153] K.-A. Cho, S.-Y. Ju, S. J. Cho et al., "Mesenchymal stem cells showed the highest potential for the regeneration of injured liver tissue compared with other subpopulations of the bone marrow," Cell Biology International, vol. 33, no. 7, pp. 772-777, 2009.

[154] I. Pascual-Miguelañez, J. Salinas-Gomez, D. FernandezLuengas et al., "Systemic treatment of acute liver failure with adipose derived stem cells," Journal of Investigative Surgery, vol. 28, no. 2, pp. 120-126, 2015.

[155] F. Salomone, I. Barbagallo, L. Puzzo, C. Piazza, and G. Li Volti, "Efficacy of adipose tissue-mesenchymal stem cell transplantation in rats with acetaminophen liver injury," Stem Cell Research, vol. 11, no. 3, pp. 1037-1044, 2013.

[156] X. Zhu, B. He, X. Zhou, and J. Ren, "Effects of transplanted bone-marrow-derived mesenchymal stem cells in animal models of acute hepatitis," Cell and Tissue Research, vol. 351, no. 3, pp. 477-486, 2013. 
[157] G. Chamberlain, J. Fox, B. Ashton, and J. Middleton, "Concise review: mesenchymal stem cells: their phenotype, differentiation capacity, immunological features, and potential for homing," Stem Cells, vol. 25, no. 11, pp. 2739-2749, 2007.

[158] A. Gebler, O. Zabel, and B. Seliger, "The immunomodulatory capacity of mesenchymal stem cells," Trends in Molecular Medicine, vol. 18, no. 2, pp. 128-134, 2012.

[159] K.-A. Cho, S.-Y. Woo, J.-Y. Seoh, H.-S. Han, and K.-H. Ryu, "Mesenchymal stem cells restore $\mathrm{CCl}_{4}$-induced liver injury by an antioxidative process," Cell Biology International, vol. 36, no. 12, pp. 1267-1274, 2012.

[160] L. F. Quintanilha, T. Takami, Y. Hirose et al., "Canine mesenchymal stem cells show antioxidant properties against thioacetamide-induced liver injury in vitro and in vivo," Hepatology Research, vol. 44, no. 10, pp. E206-E217, 2014.

[161] E. R. Marsden, Z. Hu, K. Fujio, H. Nakatsukasa, S. S. Thorgeirsson, and R. P. Evarts, "Expression of acidic fibroblast growth factor in regenerating liver and during hepatic differentiation," Laboratory Investigation, vol. 67, no. 4, pp. 427-433, 1992.

[162] G. K. Michalopoulos, "Liver regeneration after partial hepatectomy: critical analysis of mechanistic dilemmas," The American Journal of Pathology, vol. 176, no. 1, pp. 2-13, 2010.

[163] K. Nozawa, Y. Kurumiya, A. Yamamoto, Y. Isobe, M. Suzuki, and S. Yoshida, "Up-regulation of telomerase in primary cultured rat hepatocytes," The Journal of Biochemistry, vol. 126, no. 2, pp. 361-367, 1999.

[164] E. M. Webber, P. J. Godowski, and N. Fausto, "In vivo response of hepatocytes to growth factors requires an initial priming stimulus," Hepatology, vol. 19, no. 2, pp. 489-497, 1994.

[165] S. U. Kim, H. J. Oh, I. R. Wanless, S. Lee, K.-H. Han, and Y. N. Park, "The Laennec staging system for histological subclassification of cirrhosis is useful for stratification of prognosis in patients with liver cirrhosis," Journal of Hepatology, vol. 57, no. 3, pp. 556-563, 2012.

[166] L. Wang, X. Wang, L. Wang et al., "Hepatic vascular endothelial growth factor regulates recruitment of rat liver sinusoidal endothelial cell progenitor cells," Gastroenterology, vol. 143, no. 6, pp. 1555-e2, 2012.

[167] C. Lange, P. Bassler, M. V. Lioznov et al., "Liver-specific gene expression in mesenchymal stem cells is induced by liver cells," World Journal of Gastroenterology, vol. 11, no. 29, pp. 4497-4504, 2005.

[168] J. M. Luk, P. P. Wang, C. K. Lee, J. H. Wang, and S. T. Fan, "Hepatic potential of bone marrow stromal cells: development of in vitro co-culture and intra-portal transplantation models," Journal of Immunological Methods, vol. 305, no. 1, pp. 39-47, 2005.

[169] A. Banas, T. Teratani, Y. Yamamoto et al., "Rapid hepatic fate specification of adipose-derived stem cells and their therapeutic potential for liver failure," Journal of Gastroenterology and Hepatology, vol. 24, no. 1, pp. 70-77, 2009.

[170] N. Ishkitiev, K. Yaegaki, B. Calenic et al., "Deciduous and permanent dental pulp mesenchymal cells acquire hepatic morphologic and functional features in vitro," Journal of Endodontics, vol. 36, no. 3, pp. 469-474, 2010.

[171] K.-D. Lee, T. K.-C. Kuo, J. Whang-Peng et al., "In vitro hepatic differentiation of human mesenchymal stem cells," Hepatology, vol. 40, no. 6, pp. 1275-1284, 2004.

[172] L. Ling, Y. Ni, Q. Wang et al., "Transdifferentiation of mesenchymal stem cells derived from human fetal lung to hepatocyte-like cells," Cell Biology International, vol. 32, no. 9, pp. 1091-1098, 2008.
[173] M. J. Seo, S. Y. Suh, Y. C. Bae, and J. S. Jung, "Differentiation of human adipose stromal cells into hepatic lineage in vitro and in vivo," Biochemical and Biophysical Research Communications, vol. 328, no. 1, pp. 258-264, 2005.

[174] Y.-B. Zheng, Z.-L. Gao, C. Xie et al., "Characterization and hepatogenic differentiation of mesenchymal stem cells from human amniotic fluid and human bone marrow: a comparative study," Cell Biology International, vol. 32, no. 11, pp. 1439-1448, 2008.

[175] A. Xagorari, E. Siotou, M. Yiangou et al., "Protective effect of mesenchymal stem cell-conditioned medium on hepatic cell apoptosis after acute liver injury," International Journal of Clinical and Experimental Pathology, vol. 6, no. 5, pp. 831-840, 2013.

[176] D. van Poll, B. Parekkadan, C. H. Cho et al., "Mesenchymal stem cell-derived molecules directly modulate hepatocellular death and regeneration in vitro and in vivo," Hepatology, vol. 47, no. 5, pp. 1634-1643, 2008.

[177] B. Parekkadan, D. van Poll, K. Suganuma et al., "Mesenchymal stem cell-derived molecules reverse fulminant hepatic failure," PLoS ONE, vol. 2, no. 9, article e941, 2007.

[178] S. Yuan, T. Jiang, R. Zheng, L. Sun, G. Cao, and Y. Zhang, "Effect of bone marrow mesenchymal stem cell transplantation on acute hepatic failure in rats," Experimental and Therapeutic Medicine, vol. 8, no. 4, pp. 1150-1158, 2014.

[179] S. Zhang, L. Chen, T. Liu et al., "Human umbilical cord matrix stem cells efficiently rescue acute liver failure through paracrine effects rather than hepatic differentiation," Tissue Engineering Part A, vol. 18, no. 13-14, pp. 1352-1364, 2012.

[180] Y. O. Jang, M. Y. Kim, M. Y. Cho, S. K. Baik, Y. Z. Cho, and S. O. Kwon, "Effect of bone marrow-derived mesenchymal stem cells on hepatic fibrosis in a thioacetamide-induced cirrhotic rat model," BMC Gastroenterology, vol. 14, no. 1, article 198, 2014.

[181] D. C. Zhao, J. X. Lei, R. Chen et al., "Bone marrow-derived mesenchymal stem cells protect against experimental liver fibrosis in rats," World Journal of Gastroenterology, vol. 11, no. 22, pp. 3431-3440, 2005.

[182] Y. Wang, F. Lian, J. Li et al., "Adipose derived mesenchymal stem cells transplantation via portal vein improves microcirculation and ameliorates liver fibrosis induced by CCl4 in rats," Journal of Translational Medicine, vol. 10, no. 1, article 133, 2012.

[183] F. Yu, S. Ji, L. Su et al., "Adipose-derived mesenchymal stem cells inhibit activation of hepatic stellate cells invitro and ameliorate rat liver fibrosis invivo," Journal of the Formosan Medical Association, vol. 114, no. 2, pp. 130-138, 2015.

[184] V. Ninichuk, O. Gross, S. Segerer et al., "Multipotent mesenchymal stem cells reduce interstitial fibrosis but do not delay progression of chronic kidney disease in collagen4A3-deficient mice," Kidney International, vol. 70, no. 1, pp. 121-129, 2006.

[185] S. Ohnishi, H. Sumiyoshi, S. Kitamura, and N. Nagaya, "Mesenchymal stem cells attenuate cardiac fibroblast proliferation and collagen synthesis through paracrine actions," FEBS Letters, vol. 581, no. 21, pp. 3961-3966, 2007.

[186] L. A. Ortiz, F. Gambelli, C. McBride et al., "Mesenchymal stem cell engraftment in lung is enhanced in response to bleomycin exposure and ameliorates its fibrotic effects," Proceedings of the National Acadamy of Sciences of the United States of America, vol. 100, no. 14, pp. 8407-8411, 2003.

[187] M. Rojas, J. Xu, C. R. Woods et al., "Bone marrow-derived mesenchymal stem cells in repair of the injured lung," American Journal of Respiratory Cell and Molecular Biology, vol. 33, no. 2, pp. 145-152, 2005. 
[188] I. Aurich, L. P. Mueller, H. Aurich et al., "Functional integration of hepatocytes derived from human mesenchymal stem cells into mouse livers," Gut, vol. 56, no. 3, pp. 405-415, 2007.

[189] L.-J. Dai, H. Y. Li, L.-X. Guan, G. Ritchie, and J. X. Zhou, “The therapeutic potential of bone marrow-derived mesenchymal stem cells on hepatic cirrhosis," Stem Cell Research, vol. 2, no. 1, pp. 16-25, 2009.

[190] T. K. Kuo, S.-P. Hung, C.-H. Chuang et al., "Stem cell therapy for liver disease: parameters governing the success of using bone marrow mesenchymal stem cells," Gastroenterology, vol. 134, no. 7, pp. 2111.e3-2121.e3, 2008.

[191] V. Rabani, M. Shahsavani, M. Gharavi, A. Piryaei, Z. Azhdari, and H. Baharvand, "Mesenchymal stem cell infusion therapy in a carbon tetrachloride-induced liver fibrosis model affects matrix metalloproteinase expression," Cell Biology International, vol. 34, no. 6, pp. 601-605, 2010.

[192] Y. Sato, H. Araki, J. Kato et al., "Human mesenchymal stem cells xenografted directly to rat liver are differentiated into human hepatocytes without fusion," Blood, vol. 106, no. 2, pp. 756-763, 2005.

[193] S. Pulavendran, J. Vignesh, and C. Rose, "Differential antiinflammatory and anti-fibrotic activity of transplanted mesenchymal vs. Hematopoietic stem cells in carbon tetrachlorideinduced liver injury in mice," International Immunopharmacology, vol. 10, no. 4, pp. 513-519, 2010.

[194] N. Lin, K. Hu, S. Chen et al., "Nerve growth factor-mediated paracrine regulation of hepatic stellate cells by multipotent mesenchymal stromal cells," Life Sciences, vol. 85, no. 7-8, pp. 291-295, 2009.

[195] B. Parekkadan, D. van Poll, Z. Megeed et al., "Immunomodulation of activated hepatic stellate cells by mesenchymal stem cells," Biochemical and Biophysical Research Communications, vol. 363, no. 2, pp. 247-252, 2007.

[196] T. Kinnaird, E. S. Burnett, M. Shou et al., "Local delivery of marrow-derived stromal cells augments collateral perfusion through paracrine mechanisms," Circulation, vol. 109, no. 12, pp. 1543-1549, 2004.

[197] M. F. Pittenger, "Mesenchymal stem cells from adult bone marrow," Methods in Molecular Biology, vol. 449, pp. 27-44, 2008.

[198] J. A. Thomson, J. Itskovitz-Eldor, S. S. Shapiro et al., "Embryonic stem cell lines derived from human blastocysts," Science, vol. 282, no. 5391, pp. 1145-1147, 1998.

[199] G. Brolén, L. Sivertsson, P. Björquist et al., "Hepatocyte-like cells derived from human embryonic stem cells specifically via definitive endoderm and a progenitor stage," Journal of Biotechnology, vol. 145, no. 3, pp. 284-294, 2010.

[200] D. C. Hay, J. Fletcher, C. Payne et al., "Highly efficient differentiation of hESCs to functional hepatic endoderm requires ActivinA and Wnt3a signaling," Proceedings of the National Acadamy of Sciences of the United States of America, vol. 105, no. 34, pp. 12301-12306, 2008.

[201] D.-H. Woo, S.-K. Kim, H.-J. Lim et al., "Direct and indirect contribution of human embryonic stem cellderived hepatocytelike cells to liver repair in mice," Gastroenterology, vol. 142, no. 3, pp. 602-611, 2012.

[202] K. Cameron, R. Tan, W. Schmidt-Heck et al., "Recombinant Laminins Drive the Differentiation and Self-Organization of hESC-Derived Hepatocytes," Stem Cell Reports, vol. 5, no. 6, pp. 1250-1262, 2015.

[203] Y. Duan, A. Catana, Y. Meng et al., "Differentiation and enrichment of hepatocyte-like cells from human embryonic stem cells in vitro and in vivo," Stem Cells, vol. 25, no. 12, pp. 3058-3068, 2007.

[204] N. Lavon, O. Yanuka, and N. Benvenisty, "Differentiation and isolation of hepatic-like cells from human embryonic stem cells," Differentiation, vol. 72, no. 5, pp. 230-238, 2004.

[205] H. Rashidi, S. Alhaque, D. Szkolnicka, O. Flint, and D. C. Hay, "Fluid shear stress modulation of hepatocyte-like cell function," Archives of Toxicology, vol. 90, no. 7, pp. 1757-1761, 2016.

[206] G. M. Morrison, I. Oikonomopoulou, R. P. Migueles et al., "Anterior definitive endoderm from ESCs reveals a role for FGF signaling," Cell Stem Cell, vol. 3, no. 4, pp. 402-415, 2008.

[207] S. Agarwal, K. L. Holton, and R. Lanza, "Efficient differentiation of functional hepatocytes from human embryonic stem cells," Stem Cells, vol. 26, no. 5, pp. 1117-1127, 2008.

[208] J. Cai, Y. Zhao, Y. Liu et al., "Directed differentiation of human embryonic stem cells into functional hepatic cells," Hepatology, vol. 45 , no. 5, pp. 1229-1239, 2007.

[209] S. J. Forbes, S. Gupta, and A. Dhawan, "Cell therapy for liver disease: from liver transplantation to cell factory," Journal of Hepatology, vol. 62, no. 1, supplement, pp. S157-S169, 2015.

[210] H. Basma, A. Soto-Gutiérrez, G. R. Yannam et al., "Differentiation and transplantation of human embryonic stem cell-derived hepatocytes," Gastroenterology, vol. 136, no. 3, pp. 990.e4999.e4, 2009.

[211] Y. Duan, X. Ma, W. E. I. Zou et al., "Differentiation and characterization of metabolically functioning hepatocytes from human embryonic stem cells," Stem Cells, vol. 28, no. 4, pp. 674686, 2010.

[212] T. N. Bukong, T. Lo, G. Szabo, and A. Dolganiuc, "Novel developmental biology-based protocol of embryonic stem cell differentiation to morphologically sound and functional yet immature hepatocytes," Liver International, vol. 32, no. 5, pp. 732-741, 2012.

[213] D. C. Hay, D. Zhao, J. Fletcher et al., "Efficient differentiation of hepatocytes from human embryonic stem cells exhibiting markers recapitulating liver development in vivo," Stem Cells, vol. 26, no. 4, pp. 894-902, 2008.

[214] C. N. Medine, B. Lucendo-Villarin, C. Storck et al., "Developing high-fidelity hepatotoxicity models from pluripotent stem cells," Stem Cells Translational Medicine, vol. 2, no. 7, pp. 505509, 2013.

[215] N. S. Sharma, E. J. Wallenstein, E. Novik, T. Maguire, R. Schloss, and M. L. Yarmush, "Enrichment of hepatocyte-like cells with upregulated metabolic and differentiated function derived from embryonic stem cells using s-nitrosoacetylpenicillamine," Tissue Engineering - Part C: Methods, vol. 15, no. 2, pp. 297-306, 2009.

[216] T. Touboul, N. R. F. Hannan, S. Corbineau et al., "Generation of functional hepatocytes from human embryonic stem cells under chemically defined conditions that recapitulate liver development," Hepatology, vol. 51, no. 5, pp. 1754-1765, 2010.

[217] N. Tuleuova, J. Y. Lee, J. Lee, E. Ramanculov, M. A. Zern, and A. Revzin, "Using growth factor arrays and micropatterned cocultures to induce hepatic differentiation of embryonic stem cells," Biomaterials, vol. 31, no. 35, pp. 9221-9231, 2010.

[218] H. Yamamoto, G. Quinn, A. Asari et al., "Differentiation of embryonic stem cells into hepatocytes: Biological functions and therapeutic application," Hepatology, vol. 37, no. 5, pp. 983-993, 2003.

[219] L. Tolosa, J. Caron, Z. Hannoun et al., "Transplantation of hESC-derived hepatocytes protects mice from liver injury," Stem Cell Research \& Therapy, vol. 6, article 246, 2015. 
[220] K. Moriya, M. Yoshikawa, K. Saito et al., "Embryonic stem cells develop into hepatocytes after intrasplenic transplantation in $\mathrm{CCl}_{4}$-treated mice," World Journal of Gastroenterology, vol. 13, no. 6, pp. 866-873, 2007.

[221] O. Cooper, G. Hargus, M. Deleidi et al., "Differentiation of human ES and Parkinson's disease iPS cells into ventral midbrain dopaminergic neurons requires a high activity form of SHH, FGF8a and specific regionalization by retinoic acid," Molecular and Cellular Neuroscience, vol. 45, no. 3, pp. 258-266, 2010.

[222] S. Nori, Y. Okada, A. Yasuda et al., "Grafted human-induced pluripotent stem-cell-derived neurospheres promote motor functional recovery after spinal cord injury in mice," Proceedings of the National Acadamy of Sciences of the United States of America, vol. 108, no. 40, pp. 16825-16830, 2011.

[223] T. Tanaka, S. Tohyama, M. Murata et al., "In vitro pharmacologic testing using human induced pluripotent stem cellderived cardiomyocytes," Biochemical and Biophysical Research Communications, vol. 385, no. 4, pp. 497-502, 2009.

[224] N. Yokoo, S. Baba, S. Kaichi et al., "The effects of cardioactive drugs on cardiomyocytes derived from human induced pluripotent stem cells," Biochemical and Biophysical Research Communications, vol. 387, no. 3, pp. 482-488, 2009.

[225] J. Zhang, G. F. Wilson, A. G. Soerens et al., "Functional cardiomyocytes derived from human induced pluripotent stem cells," Circulation Research, vol. 104, no. 4, pp. e30-e41, 2009.

[226] K.-D. Choi, J. Yu, K. Smuga-Otto et al., "Hematopoietic and endothelial differentiation of human induced pluripotent stem cells," Stem Cells, vol. 27, no. 3, pp. 559-567, 2009.

[227] K. Tateishi, J. He, O. Taranova, G. Liang, A. C. D'Alessio, and Y. Zhang, "Generation of insulin-secreting islet-like clusters from human skin fibroblasts," The Journal of Biological Chemistry, vol. 283, no. 46, pp. 31601-31607, 2008.

[228] S. Gerbal-Chaloin, N. Funakoshi, A. Caillaud, C. Gondeau, B. Champon, and K. Si-Tayeb, "Human induced pluripotent stem cells in hepatology: beyond the proof of concept," The American Journal of Pathology, vol. 184, no. 2, pp. 332-347, 2014.

[229] Y. Kondo, T. Iwao, K. Nakamura et al., "An efficient method for differentiation of human induced pluripotent stem cells into hepatocyte-like cells retaining drug metabolizing activity," Drug Metabolism and Pharmacokinetics, vol. 29, no. 3, pp. 237-243, 2014.

[230] H. Okano, M. Nakamura, K. Yoshida et al., "Steps toward safe cell therapy using induced pluripotent stem cells," Circulation Research, vol. 112, no. 3, pp. 523-533, 2013.

[231] Z. Song, J. Cai, Y. Liu et al., "Efficient generation of hepatocytelike cells from human induced pluripotent stem cells," Cell Research, vol. 19, no. 11, pp. 1233-1242, 2009.

[232] M. Baxter, S. Withey, S. Harrison et al., "Phenotypic and functional analyses show stem cell-derived hepatocyte-like cells better mimic fetal rather than adult hepatocytes," Journal of Hepatology, vol. 62, no. 3, pp. 581-589, 2015.

[233] G. J. Sullivan, D. C. Hay, I.-H. Park et al., "Generation of functional human hepatic endoderm from human induced pluripotent stem cells," Hepatology, vol. 51, no. 1, pp. 329-335, 2010.

[234] Y.-F. Chen, C.-Y. Tseng, H.-W. Wang, H.-C. Kuo, V. W. Yang, and O. K. Lee, "Rapid generation of mature hepatocyte-like cells from human induced pluripotent stem cells by an efficient three-step protocol," Hepatology, vol. 55, no. 4, pp. 1193-1203, 2012.
[235] S. Asgari, M. Moslem, K. Bagheri-Lankarani, B. Pournasr, M. Miryounesi, and H. Baharvand, "Differentiation and Transplantation of Human Induced Pluripotent Stem Cell-derived Hepatocyte-like Cells," Stem Cell Reviews and Reports, vol. 9, no. 4, pp. 493-504, 2013.

[236] K. Takayama, M. Inamura, K. Kawabata et al., "Generation of metabolically functioning hepatocytes from human pluripotent stem cells by FOXA2 and HNF1 $\alpha$ transduction," Journal of Hepatology, vol. 57, no. 3, pp. 628-636, 2012.

[237] K. Takayama, M. Inamura, K. Kawabata et al., "Efficient generation of functional hepatocytes from human embryonic stem cells and induced pluripotent stem cells by HNF $4 \alpha$ transduction," Molecular Therapy, vol. 20, no. 1, pp. 127-137, 2012.

[238] Q. Zhang, Y. Yang, J. Zhang et al., "Efficient derivation of functional hepatocytes from mouse induced pluripotent stem cells by a combination of cytokines and sodium butyrate," Chinese Medical Journal, vol. 124, no. 22, pp. 3786-3793, 2011.

[239] A. Ghodsizadeh, A. Taei, M. Totonchi et al., "Generation of liver disease-specific induced pluripotent stem cells along with efficient differentiation to functional hepatocyte-like cells," Stem Cell Reviews and Reports, vol. 6, no. 4, pp. 622-632, 2010.

[240] S. T. Rashid, S. Corbineau, N. Hannan et al., "Modeling inherited metabolic disorders of the liver using human induced pluripotent stem cells," The Journal of Clinical Investigation, vol. 120, no. 9, pp. 3127-3136, 2010.

[241] P. Sancho-Bru, P. Roelandt, N. Narain et al., "Directed differentiation of murine-induced pluripotent stem cells to functional hepatocyte-like cells," Journal of Hepatology, vol. 54, no. 1, pp. 98-107, 2011.

[242] S. Zhang, S. Chen, W. Li et al., "Rescue of ATP7B function in hepatocyte-like cells from Wilson's disease induced pluripotent stem cells using gene therapy or the chaperone drug curcumin," Human Molecular Genetics, vol. 20, no. 16, Article ID ddr223, pp. 3176-3187, 2011.

[243] S. Espejel, G. R. Roll, and K. J. McLaughlin, "Induced pluripotent stem cell-derived hepatocytes have the functional and proliferative capabilities needed for liver regeneration in mice," The Journal of Clinical Investigation, vol. 120, no. 9, pp. 31203126, 2010.

[244] K. Yusa, S. T. Rashid, H. Strick-Marchand et al., “Targeted gene correction of alphal-antitrypsin deficiency in induced pluripotent stem cells," Nature, vol. 478, no. 7369, pp. 391-394, 2011.

[245] J. Harding and O. Mirochnitchenko, "Preclinical studies for induced pluripotent stem cell-based therapeutics," The Journal of Biological Chemistry, vol. 289, no. 8, pp. 4585-4593, 2014.

[246] V. K. Singh, M. Kalsan, N. Kumar, A. Saini, and R. Chandra, "Induced pluripotent stem cells: applications in regenerative medicine, disease modeling, and drug discovery," Frontiers in Cell and Developmental Biology, vol. 3, no. 2, 2015.

[247] S. J. Yu, J.-H. Yoon, W. Kim et al., "Ultrasound-guided percutaneous portal transplantation of peripheral blood monocytes in patients with liver cirrhosis," Korean Journal of Internal Medicine, vol. 32, no. 2, pp. 261-268, 2017.

[248] T. Zhao, Z.-N. Zhang, Z. Rong, and Y. Xu, "Immunogenicity of induced pluripotent stem cells," Nature, vol. 474, no. 7350, pp. 212-215, 2011.

[249] R. Araki, M. Uda, Y. Hoki et al., "Negligible immunogenicity of terminally differentiated cells derived from induced pluripotent or embryonic stem cells," Nature, vol. 494, no. 7435, pp. 100-104, 2013. 
[250] L. Tolosa, E. Pareja, and M. J. Gómez-Lechón, “Clinical Application of Pluripotent Stem Cells: An Alternative Cell-Based Therapy for Treating Liver Diseases?" Transplantation, vol. 100, no. 12, pp. 2548-2557, 2016.

[251] Y. Haruna, K. Saito, S. Spaulding, M. A. Nalesnik, and M. A. Gerber, "Identification of bipotential progenitor cells in human liver development," Hepatology, vol. 23, no. 3, pp. 476-481, 1996.

[252] E. Schmelzer, L. Zhang, A. Bruce et al., "Human hepatic stem cells from fetal and postnatal donors," The Journal of Experimental Medicine, vol. 204, no. 8, pp. 1973-1987, 2007.

[253] N. Shiojiri and T. Mizuno, "Differentiation of functional hepatocytes and biliary epithelial cells from immature hepatocytes of the fetal mouse in vitro," Anatomy and Embryology, vol. 187, no. 3, pp. 221-229, 1993.

[254] T. Cantz, D. M. Zuckerman, M. R. Burda et al., "Quantitative gene expression analysis reveals transition of fetal liver progenitor cells to mature hepatocytes after transplantation in uPA/RAG-2 mice," The American Journal of Pathology, vol. 162, no. 1, pp. 37-45, 2003.

[255] M. Oertel, A. Menthena, Y.-Q. Chen, B. Teisner, C. H. Jensen, and D. A. Shafritz, "Purification of fetal liver stem/progenitor cells containing all the repopulation potential for normal adult rat liver," Gastroenterology, vol. 134, no. 3, pp. 823-832, 2008.

[256] J. S. Sandhu, P. M. Petkov, M. D. Dabeva, and D. A. Shafritz, "Stem cell properties and repopulation of the rat liver by fetal liver epithelial progenitor cells," The American Journal of Pathology, vol. 159, no. 4, pp. 1323-1334, 2001.

[257] C. van de Ven, D. Collins, M. B. Bradley, E. Morris, and M. S. Cairo, "The potential of umbilical cord blood multipotent stem cells for nonhematopoietic tissue and cell regeneration," Experimental Hematology, vol. 35, no. 12, pp. 1753-1765, 2007.

[258] D. Campard, P. A. Lysy, M. Najimi, and E. M. Sokal, "Native umbilical cord matrix stem cells express hepatic markers and differentiate into hepatocyte-like cells," Gastroenterology, vol. 134, no. 3, pp. 833-848, 2008.

[259] K. Teramoto, K. Asahina, Y. Kumashiro et al., "Hepatocyte differentiation from embryonic stem cells and umbilical cord blood cells," Journal of Hepato-Biliary-Pancreatic Sciences, vol. 12, no. 3, pp. 196-202, 2005.

[260] C.-C. Chien, B. L. Yen, F.-K. Lee et al., "In vitro differentiation of human placenta-derived multipotent cells into hepatocyte-like cells," Stem Cells, vol. 24, no. 7, pp. 1759-1768, 2006.

[261] M. Bhatia, A. G. Elefanty, S. J. Fisher, R. Patient, T. Schlaeger, and E. Y. Snyder, Current Protocols in Stem Cell Biology, John Wiley \& Sons, Inc., Hoboken, NJ, USA, 2007.

[262] S. Lorenzini and P. Andreone, "Stem cell therapy for human liver cirrhosis: A cautious analysis of the results," Stem Cells, vol. 25, no. 9, pp. 2383-2384, 2007.

[263] Y. Q. Xu and Z. C. Liu, "Therapeutic Potential of Adult Bone Marrow Stem Cells in Liver Disease and Delivery Approaches," Stem Cell Reviews and Reports, vol. 4, no. 2, pp. 101-112, 2008.

[264] M. Y. Gordon, N. Levičar, M. Pai et al., "Characterization and clinical application of human $\mathrm{CD}_{3} 4^{+}$stem/progenitor cell populations mobilized into the blood by granulocyte colonystimulating factor," Stem Cells, vol. 24, no. 7, pp. 1822-1830, 2006.

[265] A. A. Khan, N. Parveen, V. S. Mahaboob et al., "Safety and Efficacy of Autologous Bone Marrow Stem Cell Transplantation Through Hepatic Artery for the Treatment of Chronic Liver Failure: A Preliminary Study," Transplantation Proceedings, vol. 40, no. 4, pp. 1140-1144, 2008.
[266] J. K. Kim, Y. N. Park, J. S. Kim et al., "Autologous bone marrow infusion activates the progenitor cell compartment in patients with advanced liver cirrhosis," Cell Transplantation, vol. 19, no. 10, pp. 1237-1246, 2010.

[267] M. Mohamadnejad, K. Alimoghaddam, M. Mohyeddin-Bonab et al., "Phase 1 trial of autologous bone marrow mesenchymal stem cell transplantation in patients with decompensated liver cirrhosis," Archives of Iranian Medicine, vol. 10, no. 4, pp. 459466, 2007.

[268] M. Mohamadnejad, M. Namiri, M. Bagheri et al., "Phase 1 human trial of autologous bone marrow-hematopoietic stem cell transplantation in patients with decompensated cirrhosis," World Journal of Gastroenterology, vol. 13, no. 24, pp. 3359-3363, 2007.

[269] H. Salama, A.-R. Zekri, M. Zern et al., "Autologous hematopoietic stem cell transplantation in 48 patients with end-stage chronic liver diseases," Cell Transplantation, vol. 19, no. 11, pp. 1475-1486, 2010.

[270] E. Yannaki, A. Anagnostopoulos, D. Kapetanos et al., "Lasting amelioration in the clinical course of decompensated alcoholic cirrhosis with boost infusions of mobilized peripheral blood stem cells," Experimental Hematology, vol. 34, no. 11, pp. 15831587, 2006.

[271] J. Schulte Am Esch II, W. T. Knoefel, M. Klein et al., "Portal application of autologous $\mathrm{CD} 133^{+}$bone marrow cells to the liver: a novel concept to support hepatic regeneration," Stem Cells, vol. 23, no. 4, pp. 463-470, 2005.

[272] G. Fürst, J. Schulte Am Esch, L. W. Poll et al., "Portal vein embolization and autologous CD133+ bone marrow stem cells for liver regeneration: Initial experience," Radiology, vol. 243, no. 1, pp. 171-179, 2007.

[273] A. Ismail, A. Aldorry, M. Shaker et al., "Simultaneous injection of autologous mononuclear cells with TACE in HCC patients; Preliminary study," Journal of Gastrointestinal Cancer, vol. 42, no. 1, pp. 11-19, 2011.

[274] A. E. Karnoub, A. B. Dash, A. P. Vo et al., "Mesenchymal stem cells within tumour stroma promote breast cancer metastasis," Nature, vol. 449, no. 7162, pp. 557-563, 2007.

[275] I. Matushansky, E. Hernando, N. D. Socci et al., "Derivation of sarcomas from mesenchymal stem cells via inactivation of the Wnt pathway," The Journal of Clinical Investigation, vol. 117, no. 11, pp. 3248-3257, 2007.

[276] A. A. Khan, M. V. Shaik, N. Parveen et al., "Human fetal liverderived stem cell transplantation as supportive modality in the management of end-stage decompensated liver cirrhosis," Cell Transplantation, vol. 19, no. 4, pp. 409-418, 2010.

[277] G. Lanzoni, T. Oikawa, Y. Wang et al., "Concise review: clinical programs of stem cell therapies for liver and pancreas," Stem Cells, vol. 31, no. 10, pp. 2047-2060, 2013.

[278] G. R. Burganova, "Effectiveness of autologous hematopoietic stem cells transplantation in patients with liver cirrhosis," Experimental \& Clinical Gastroenterology, vol. no. 4, pp. 91-97, 2012.

[279] A. King, D. Barton, H. A. Beard et al., "REpeated AutoLogous Infusions of STem cells in Cirrhosis (REALISTIC): a multicentre, phase II, open-label, randomised controlled trial of repeated autologous infusions of granulocyte colony-stimulating factor (GCSF) mobilised CD133+ bone marrow stem cells in patients with cirrhosis. A study protocol for a randomised controlled trial," BMJ Open, vol. 5, no. 3, Article ID e007700, 2015.

[280] C. Margini, R. Vukotic, L. Brodosi, M. Bernardi, and P. Andreone, "Bone marrow derived stem cells for the treatment of 
end-stage liver disease," World Journal of Gastroenterology, no. 27, pp. 9098-9105, 2014.

[281] A. R. Zekri, H. Salama, and E. Medhat, "The impact of repeated autologous infusion of haematopoietic stem cells in patients with liver insufficiency," Stem Cell Research \& Therapy, vol. 6, no. 1, p. 118, 2015.

[282] M. A. Amin, D. Sabry, L. A. Rashed et al., "Short-term evaluation of autologous transplantation of bone marrow-derived mesenchymal stem cells in patients with cirrhosis: Egyptian study," Clinical Transplantation, vol. 27, no. 4, pp. 607-612, 2013.

[283] M. El-Ansary, I. Abdel-Aziz, S. Mogawer et al., "Phase II trial: undifferentiated versus differentiated autologous mesenchymal stem cells transplantation in Egyptian patients with HCV induced liver cirrhosis," Stem Cell Reviews and Reports, vol. 8, no. 3, pp. 972-981, 2012.

[284] Y. O. Jang, Y. J. Kim, S. K. Baik et al., "Histological improvement following administration of autologous bone marrow-derived mesenchymal stem cells for alcoholic cirrhosis: a pilot study," Liver International, vol. 34, no. 1, pp. 33-41, 2014.

[285] L. Peng, D.-Y. Xie, B.-L. Lin et al., "Autologous bone marrow mesenchymal stem cell transplantation in liver failure patients caused by hepatitis B: short-term and long-term outcomes," Hepatology, vol. 54, no. 3, pp. 820-828, 2011.

[286] M. Mohamadnejad, K. Alimoghaddam, M. Bagheri et al., "Randomized placebo-controlled trial of mesenchymal stem cell transplantation in decompensated cirrhosis," Liver International, vol. 33, no. 10, pp. 1490-1496, 2013.

[287] S. Berardis, P. D. Sattwika, M. Najimi, and E. M. Sokal, "Use of mesenchymal stem cells to treat liver fibrosis: current situation and future prospects," World Journal of Gastroenterology, vol. 21, no. 3, pp. 742-758, 2015.

[288] M. Shi, Z. Zhang, and R. Xu, "Human mesenchymal stem cell transfusion is safe and improves liver function in acute-onchronic liver failure patients," Stem Cells Translational Medicine, vol. 1, no. 10, pp. 725-731, 2012.

[289] L. Wang, J. Li, H. Liu et al., "A pilot study of umbilical cord-derived mesenchymal stem cell transfusion in patients with primary biliary cirrhosis," Journal of Gastroenterology and Hepatology, vol. 28, no. 1, pp. 85-92, 2013.

[290] Z. Zhang, H. Lin, M. Shi et al., "Human umbilical cord mesenchymal stem cells improve liver function and ascites in decompensated liver cirrhosis patients," Journal of Gastroenterology and Hepatology, vol. 27, supplement 2, pp. 112-120, 2012.

[291] M. Blachier, H. Leleu, M. Peck-Radosavljevic, D.-C. Valla, and F. Roudot-Thoraval, "The burden of liver disease in Europe: a review of available epidemiological data," Journal of Hepatology, vol. 58, no. 3, pp. 593-608, 2013.

[292] J. Polson and W. M. Lee, "AASLD position paper: The management of acute liver failure," Hepatology, vol. 41, no. 5, pp. 11791197, 2005.

[293] R. Jalan, P. Gines, J. C. Olson et al., "Acute-on chronic liver failure," Journal of Hepatology, vol. 57, no. 6, pp. 1336-1348, 2012.

[294] R. Williams, "Global challenges in liver disease," Hepatology, vol. 44, no. 3, pp. 521-526, 2006.

[295] N. Kemmer, A. Alsina, and G. W. Neff, "Orthotopic liver transplantation in a multiethnic population: Role of spatial accessibility," Transplantation Proceedings, vol. 43, no. 10, pp. 3780-3782, 2011.

[296] S. J. Kim, C. W. Choi, D. H. Kang et al., "Emergency endoscopic variceal ligation in cirrhotic patients with blood clots in the stomach but no active bleeding or stigmata increases the risk of rebleeding," Clinical and Molecular Hepatology, vol. 22, no. 4, pp. 466-476, 2016.

[297] I. J. Fox and J. Roy-Chowdhury, "Hepatocyte transplantation," Journal of Hepatology, vol. 40, no. 6, pp. 878-886, 2004.

[298] S. C. Strom, R. A. Fisher, M. T. Thompson et al., "Hepatocyte transplantation as a bridge to orthotopic liver transplantation in terminal liver failure," Transplantation, vol. 63, no. 4, pp. 559$569,1997$.

[299] A. Dhawan, "Clinical human hepatocyte transplantation: Current status and challenges," Liver Transplantation, vol. 21, pp. S39-S44, 2015.

[300] M. C. Hansel, R. Gramignoli, K. J. Skvorak et al., "The history and use of human hepatocytes for the treatment of liver diseases: the first 100 patients," Current Protocols in Toxicology, vol. 62, pp. 14-12, 2014.

[301] S. L. Friedman, "Liver fibrosis—from bench to bedside," Journal of Hepatology, vol. 38, supplement 1, pp. 38-53, 2003.

[302] J.-T. Li, Z.-X. Liao, J. Ping, D. Xu, and H. Wang, "Molecular mechanism of hepatic stellate cell activation and antifibrotic therapeutic strategies," Journal of Gastroenterology, vol. 43, no. 6, pp. 419-428, 2008.

[303] E. Mormone, J. George, and N. Nieto, "Molecular pathogenesis of hepatic fibrosis and current therapeutic approaches," Chemico-Biological Interactions, vol. 193, no. 3, pp. 225-231, 2011.

[304] E. Albanis and S. L. Friedman, "Antifibrotic agents for liver disease," American Journal of Transplantation, vol. 6, no. 1, pp. 12-19, 2006.

[305] M. Ismail and M. Pinzani, "Reversal of hepatic fibrosis: pathophysiological basis of antifibrotic therapies," Hepatic Medicine: Evidence and Research, pp. 69-80, 2011.

[306] D. C. Rockey, "Current and future anti-fibrotic therapies for chronic liver disease," Clinics in Liver Disease, vol. 12, no. 4, pp. 939-962, 2008.

[307] R. Belfort, S. A. Harrison, K. Brown et al., "A placebo-controlled trial of pioglitazone in subjects with nonalcoholic steatohepatitis," The New England Journal of Medicine, vol. 355, no. 22, pp. 2297-2307, 2006.

[308] P. J. Pockros, L. Jeffers, N. Afdhal et al., "Final results of a double-blind, placebo-controlled trial of the antifibrotic efficacy of interferon- $\gamma 1 \mathrm{~b}$ in chronic hepatitis $\mathrm{C}$ patients with advanced fibrosis or cirrhosis," Hepatology, vol. 45, no. 3, pp. 569-578, 2007.

[309] A. J. Sanyal, N. Chalasani, K. V. Kowdley et al., "Pioglitazone, vitamin E, or placebo for nonalcoholic steatohepatitis," The New England Journal of Medicine, vol. 362, no. 18, pp. 1675-1685, 2010.

[310] H.-L. Weng, B.-E. Wang, J.-D. Jia et al., "Effect of interferongamma on hepatic fibrosis in chronic hepatitis B virus infection: A randomized controlled study," Clinical Gastroenterology and Hepatology, vol. 3, no. 8, pp. 819-828, 2005.

[311] B. K. A. Dayyeh, M. Yang, J. L. Dienstag, and R. T. Chung, "The effects of angiotensin blocking agents on the progression of liver fibrosis in the HALT-C Trial cohort," Digestive Diseases and Sciences, vol. 56, no. 2, pp. 564-568, 2011.

[312] Q. Lang, Q. Liu, N. Xu et al., "The antifibrotic effects of TGF- $\beta 1$ siRNA on hepatic fibrosis in rats," Biochemical and Biophysical Research Communications, vol. 409, no. 3, pp. 448-453, 2011.

[313] T. Nakamura, R. Sakata, T. Ueno, M. Sata, and H. Ueno, "Inhibition of transforming growth factor $\beta$ prevents progression of liver fibrosis and enhances hepatocyte regeneration in dimethylnitrosamine- treated rats," Hepatology, vol. 32, no. 2, pp. 247-255, 2000. 
[314] M. C. Wright, R. Issa, D. E. Smart et al., "Gliotoxin stimulates the apoptosis of human and rat hepatic stellate cells and enhances the resolution of liver fibrosis in rats," Gastroenterology, vol. 121, no. 3, pp. 685-698, 2001.

[315] S. Salgado, J. Garcia, J. Vera et al., "Liver cirrhosis is reverted by urokinase-type plasminogen activator gene therapy," Molecular Therapy, vol. 2, no. 6, pp. 545-551, 2000.

[316] H. Sugino, N. Kumagai, S. Watanabe et al., "Polaprezinc attenuates liver fibrosis in a mouse model of non-alcoholic steatohepatitis," Journal of Gastroenterology and Hepatology, vol. 23, no. 12, pp. 1909-1916, 2008.

[317] E. Mezey, J. J. Potter, L. Rennie-Tankersley, J. Caballeria, and A. Pares, "A randomized placebo controlled trial of vitamin E for alcoholic hepatitis," Journal of Hepatology, vol. 40, no. 1, pp. 4046, 2004.

[318] D. R. Nelson, Z. Tu, C. Soldevila-Pico et al., "Long-term interleukin 10 therapy in chronic hepatitis $\mathrm{C}$ patients has a proviral and anti-inflammatory effect," Hepatology, vol. 38, no. 4, pp. 859-868, 2003.

[319] N. Nikolaidis, J. Kountouras, O. Giouleme et al., "Colchicine treatment of liver fibrosis," Hepato-Gastroenterology, vol. 53, no. 68, pp. 281-285, 2006.

[320] M. Esrefoglu, "Role of stem cells in repair of liver injury: Experimental and clinical benefit of transferred stem cells on liver failure," World Journal of Gastroenterology, vol. 19, no. 40, pp. 6757-6773, 2013.

[321] M. A. Habeeb, "Hepatic stem cells: A viable approach for the treatment of liver cirrhosis," World Journal of Stem Cells, vol. 7, no. 5, p. 859, 2015.

[322] C. Hu and L. Li, "In Vitro and in Vivo Hepatic Differentiation of Adult Somatic Stem Cells and Extraembryonic Stem Cells for Treating End Stage Liver Diseases," Stem Cells International, vol. 2015, Article ID 871972, 2015.

[323] P. A. Lysy, D. Campard, F. Smets et al., "Persistence of a chimerical phenotype after hepatocyte differentiation of human bone marrow mesenchymal stem cells," Cell Proliferation, vol. 41, no. 1, pp. 36-58, 2008.

[324] C. Nicolas, Y. Wang, J. Luebke-Wheeler, and S. Nyberg, "Stem Cell Therapies for Treatment of Liver Disease," Biomedicines, vol. 4, no. 1, p. 2, 2016.

[325] Y. Yu, X. Wang, and S. Nyberg, "Potential and Challenges of Induced Pluripotent Stem Cells in Liver Diseases Treatment," Journal of Clinical Medicine, vol. 3, no. 3, pp. 997-1017, 2014.

[326] R. M. Baertschiger, V. Serre-Beinier, P. Morel et al., "Fibrogenic potential of human multipotent mesenchymal stromal cells in injured liver," PLoS ONE, vol. 4, no. 8, Article ID e6657, 2009.

[327] L. V. di Bonzo, I. Ferrero, C. Cravanzola et al., "Human mesenchymal stem cells as a two-edged sword in hepatic regenerative medicine: engraftment and hepatocyte differentiation versus profibrogenic potential," Gut, vol. 57, no. 2, pp. 223-231, 2008.

[328] B. Raore, T. Federici, J. Taub et al., "Cervical multilevel intraspinal stem cell therapy: Assessment of surgical risks in gottingen minipigs," The Spine Journal, vol. 36, no. 3, pp. E164-E171, 2011.

[329] L. Xu, D. K. Ryugo, T. Pongstaporn, K. Johe, and V. E. Koliatsos, "Human neural stem cell grafts in the spinal cord of SOD1 transgenic rats: Differentiation and structural integration into the segmental motor circuitry," Journal of Comparative Neurology, vol. 514, no. 4, pp. 297-309, 2009.

[330] J. Yan, L. Xu, A. M. Welsh et al., "Extensive neuronal differentiation of human neural stem cell grafts in adult rat spinal cord," PLoS Medicine, vol. 4, no. 2, article e39, 2007.
[331] J. Chen, F. Wang, Y. Zhang et al., "In vivo tracking of superparamagnetic iron oxide nanoparticle labeled chondrocytes in large animal model.," Annals of Biomedical Engineering, vol. 40, no. 12, pp. 2568-2578, 2012.

[332] S.-L. Hu, J.-Q. Zhang, X. Hu et al., "In vitro labeling of human umbilical cord mesenchymal stem cells with superparamagnetic iron oxide nanoparticles," Journal of Cellular Biochemistry, vol. 108, no. 2, pp. 529-535, 2009.

[333] M. Neri, C. Maderna, C. Cavazzin et al., "Efficient in vitro labeling of human neural precursor cells with superparamagnetic iron oxide particles: Relevance for in vivo cell tracking," Stem Cells, vol. 26, no. 2, pp. 505-516, 2008.

[334] S. S. Yaghoubi, D. O. Campbell, C. G. Radu, and J. Czernin, "Positron emission tomography reporter genes and reporter probes: gene and cell therapy applications," Theranostics, vol. 2, no. 4, pp. 374-391, 2012.

[335] F. Wang, J. E. Dennis, A. Awadallah et al., "Transcriptional profiling of human mesenchymal stem cells transduced with reporter genes for imaging," Physiological Genomics, vol. 37, no. 1, pp. 23-34, 2009.

[336] S. J. Zhang and J. C. Wu, "Comparison of imaging techniques for tracking cardiac stem cell therapy," Journal of Nuclear Medicine, vol. 48, no. 12, pp. 1916-1919, 2007.

[337] K. T. Suk, J.-H. Yoon, M. Y. Kim et al., "Transplantation with autologous bone marrow-derived mesenchymal stem cells for alcoholic cirrhosis: Phase 2 trial," Hepatology, vol. 64, no. 6, pp. 2185-2197, 2016.

[338] R. P. H. Meier, R. Mahou, P. Morel et al., "Microencapsulated human mesenchymal stem cells decrease liver fibrosis in mice," Journal of Hepatology, vol. 62, no. 3, pp. 634-641, 2015.

[339] Y. Wang, X. Yu, E. Chen, and L. Li, "Liver-derived human mesenchymal stem cells: A novel therapeutic source for liver diseases," Stem Cell Research \& Therapy, vol. 7, no. 1, article no. 71, 2016.

[340] F. Zhang, Y. Wen, and X. Guo, "CRISPR/Cas9 for genome editing: Progress, implications and challenges," Human Molecular Genetics, vol. 23, no. 1, pp. R40-R46, 2014.

[341] C. Smith, L. Abalde-Atristain, C. He et al., "Efficient and allele-specific genome editing of disease loci in human iPSCs," Molecular Therapy, vol. 23, no. 3, pp. 570-577, 2015.

[342] M. Vosough, E. Omidinia, M. Kadivar et al., "Generation of functional hepatocyte-like cells from human pluripotent stem cells in a scalable suspension culture," Stem Cells and Development, vol. 22, no. 20, pp. 2693-2705, 2013.

[343] S. Ogawa, J. Surapisitchat, C. Virtanen et al., "Three-dimensional culture and CAMP signaling promote the maturation of human pluripotent stem cell-derived hepatocytes," Development, vol. 140, no. 15, pp. 3285-3296, 2013.

[344] M. C. Hansel, J. C. Davila, M. Vosough et al., "The Use of Induced Pluripotent Stem Cells for the Study and Treatment of Liver Diseases," Current Protocols in Toxicology, vol. 67, pp. 1413, 2016.

[345] S. M. Choi, Y. Kim, J. S. Shim et al., "Efficient drug screening and gene correction for treating liver disease using patient-specific stem cells," Hepatology, vol. 57, no. 6, pp. 2458-2468, 2013.

[346] N. Dianat, C. Steichen, L. Vallier, A. Weber, and A. DubartKupperschmitt, "Human pluripotent stem cells for modelling human liver diseases and cell therapy," Current Gene Therapy, vol. 13, no. 2, pp. 120-132, 2013.

[347] K. Hussain, B. Challis, N. Rocha et al., "An activating mutation of AKT2 and human hypoglycemia," Science, vol. 334, no. 6055, p. 474, 2011. 
[348] M. Li, K. Suzuki, N. Y. Kim, G.-H. Liu, and J. C. I. Belmonte, "A cut above the rest: targeted genome editing technologies in human pluripotent stem cells," The Journal of Biological Chemistry, vol. 289, no. 8, pp. 4594-4599, 2014.

[349] T. Egashira, S. Yuasa, and K. Fukuda, "Novel insights into disease modeling using induced pluripotent stem cells," Biological \& Pharmaceutical Bulletin, vol. 36, no. 2, pp. 182-188, 2013.

[350] R. Eggenschwiler, K. Loya, and G. Wu, "Sustained knockdown of a disease-causing gene in patient-specific induced pluripotent stem cells using lentiviral vector-based gene therapy," Stem Cells Translational Medicine, vol. 2, no. 9, pp. 641-654, 2013.

[351] U. Grieshammer and K. A. Shepard, "Proceedings: consideration of genetics in the design of induced pluripotent stem cell-based models of complex disease," Stem Cells Translational Medicine, vol. 3, no. 11, pp. 1253-1258, 2014.

[352] H. Inoue, N. Nagata, H. Kurokawa, and S. Yamanaka, "IPS cells: a game changer for future medicine," EMBO Journal, vol. 33, no. 5, pp. 409-417, 2014.

[353] F. T. Merkle and K. Eggan, "Modeling human disease with pluripotent stem cells: From genome association to function," Cell Stem Cell, vol. 12, no. 6, pp. 656-668, 2013.

[354] K. Moriya, M. Yoshikawa, Y. Ouji et al., "Embryonic stem cells reduce liver fibrosis in CCl4-treated mice," International Journal of Clinical and Experimental Pathology, vol. 89, no. 6, pp. 401409, 2008.

[355] R. Schwartz, K. Trehan, L. Andrus et al., "Su1581 Modeling Hepatitis C Virus Infection Using Human Induced Pluripotent Stem Cells," Gastroenterology, vol. 142, no. 5, p. S-971, 2012.

[356] F. Soldner and R. Jaenisch, "iPSC disease modeling," Science, vol. 338, no. 6111, pp. 1155-1156, 2012.

[357] G. Holmgren, A.-K. Sjögren, I. Barragan et al., "Long-term chronic toxicity testing using human pluripotent stem cellderived hepatocytes," Drug Metabolism and Disposition, vol. 42, no. 9, pp. 1401-1406, 2014.

[358] D. Szkolnicka, S. L. Farnworth, B. Lucendo-Villarin et al., "Accurate prediction of drug-induced liver injury using stem cell-derived populations," Stem Cells Translational Medicine, vol. 3, no. 2, pp. 141-148, 2014.

[359] D. Szkolnicka, B. Lucendo-Villarin, J. K. Moore, K. J. Simpson, S. J. Forbes, and D. C. Hay, "Reducing hepatocyte injury and necrosis in response to paracetamol using noncoding RNAs," Stem Cells Translational Medicine, vol. 5, no. 6, pp. 764-772, 2016.

[360] M. A. Cayo, J. Cai, A. Delaforest et al., "JD induced pluripotent stem cell-derived hepatocytes faithfully recapitulate the pathophysiology of familial hypercholesterolemia," Hepatology, vol. 56, no. 6, pp. 2163-2171, 2012. 


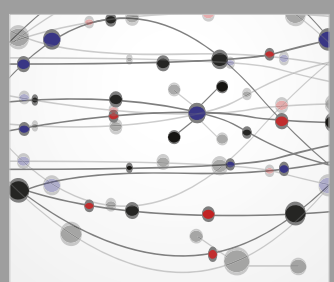

The Scientific World Journal
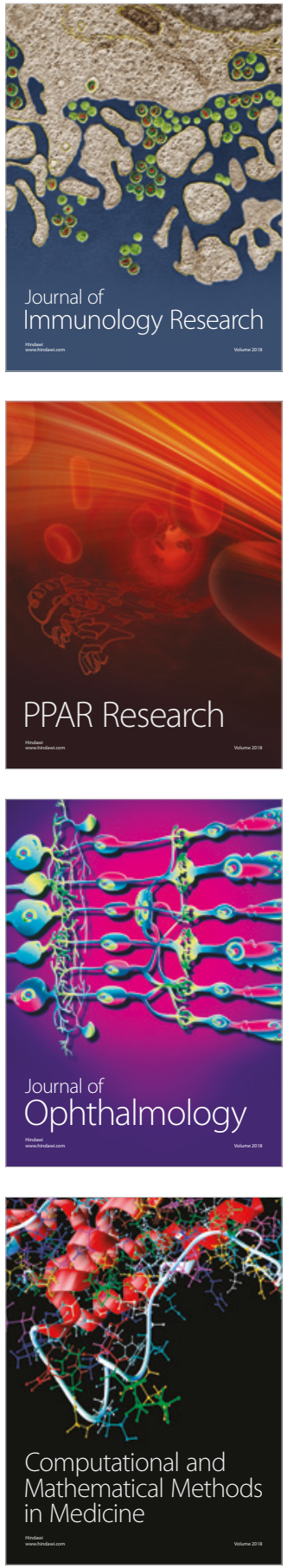

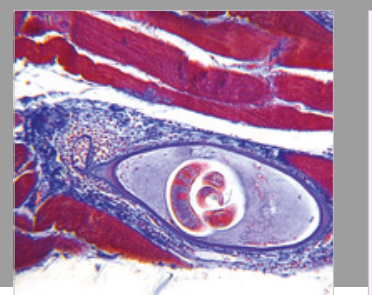

Gastroenterology Research and Practice

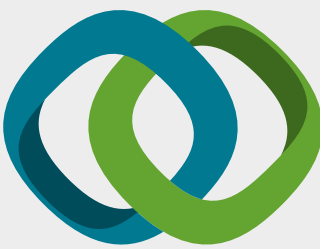

\section{Hindawi}

Submit your manuscripts at

www.hindawi.com
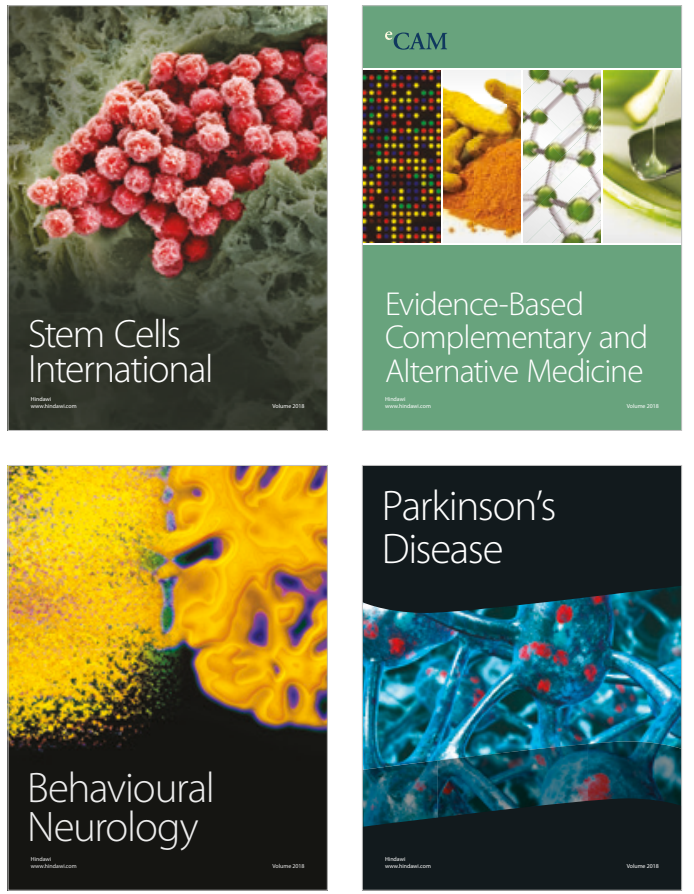

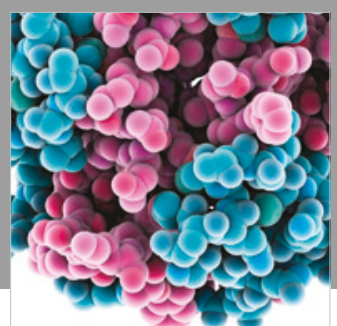

ournal of

Diabetes Research

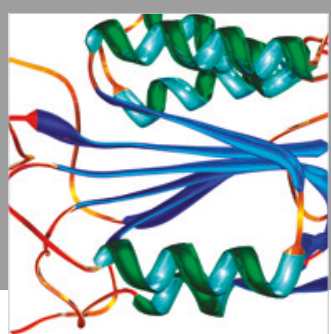

Disease Markers
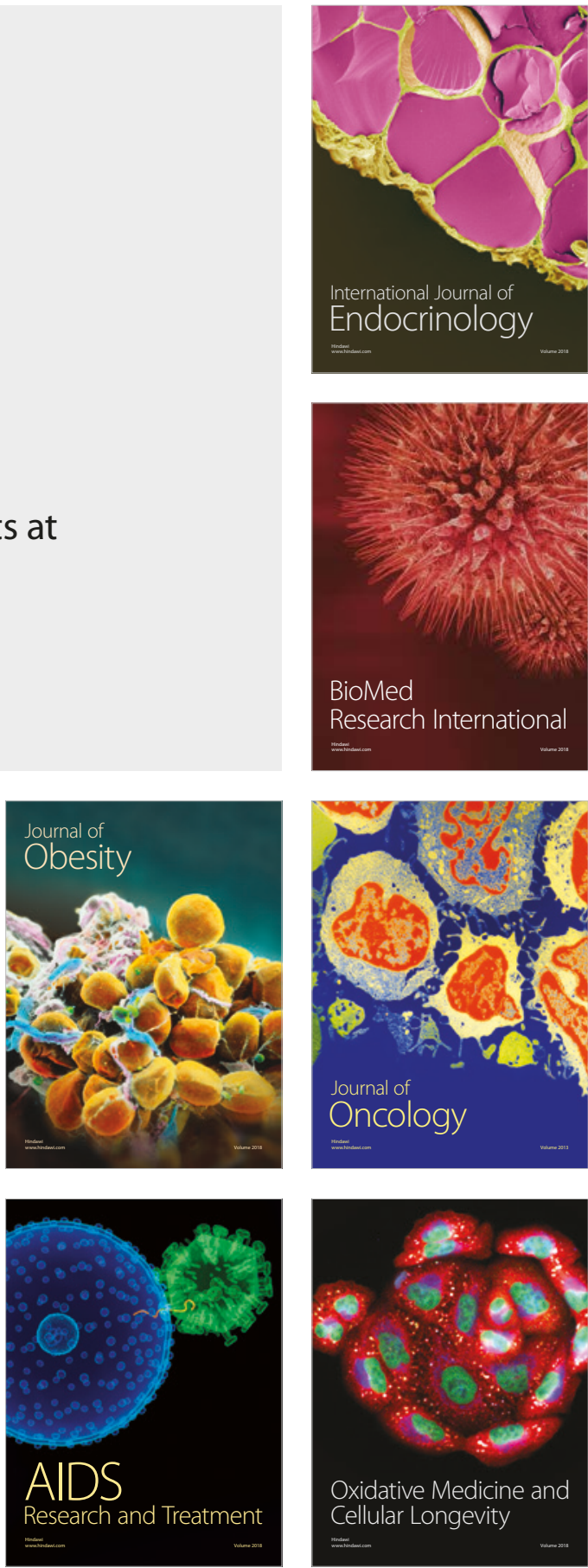